\title{
مادة (دل ل) وما يرادفها في (دلائل الإعجاز) للجرجاني
}

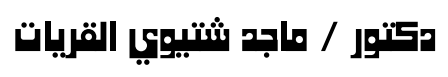

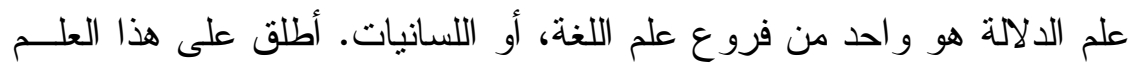

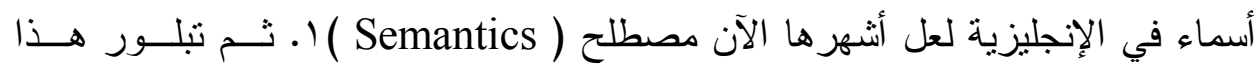
المصطلح على يد بريال في صورته الفرنسية ( Semantique ) في نهايـات القــرن

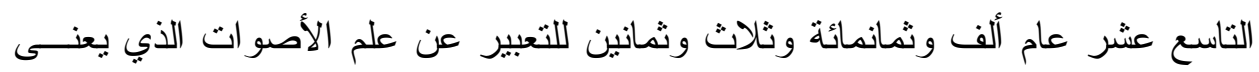

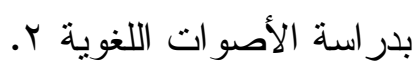
وقد ارتبط هذا لعلم بادئ ذي بدء بالفلسفة و المنطق أكثر مــن ارتباطــــهـ بــأي

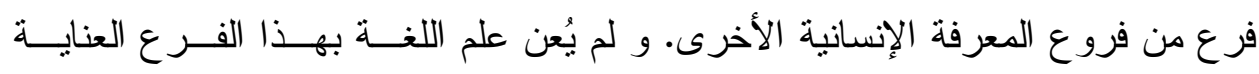

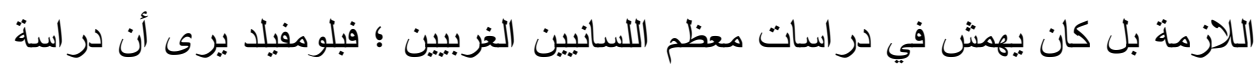

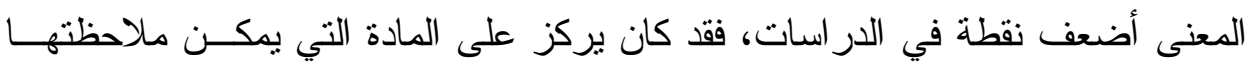

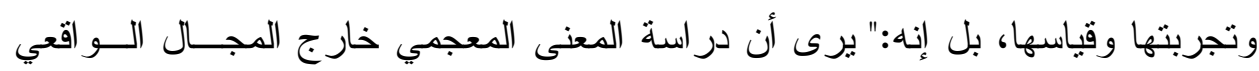

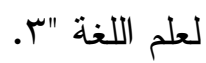

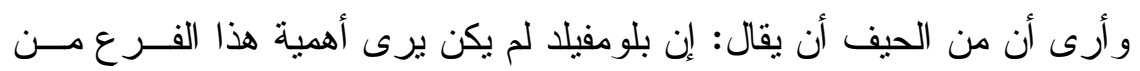

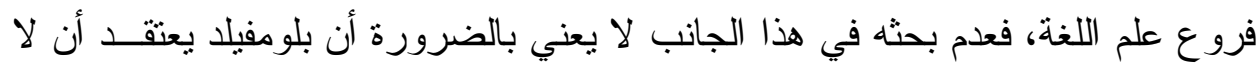

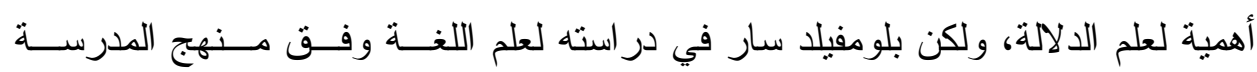

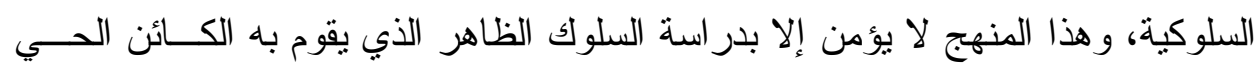

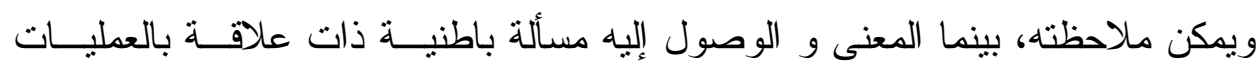
العقلية التي يعسر على الباحث إخضاعها للملاحظة و التجريب ؛ فبلومفيلد كان معذورا بأنها في عدم بحثه للمعنى إذا ما حوكم وفق المنهج الذي تبني التباه.

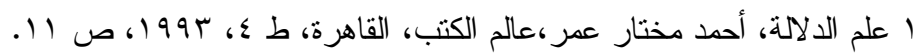

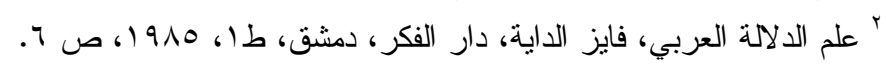

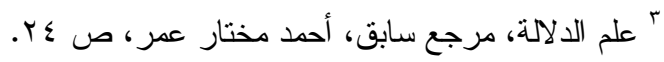


و لم يقحم تشومسكي المكون الدلالي في النظرية التوليدية التحويليــة إلا فــي مستوى متأخر من مستويات هذه النظرية الـ و و لعل الملاحظات التي أبداها معاصــروه

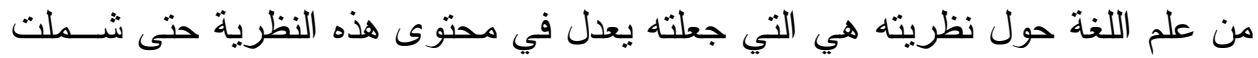

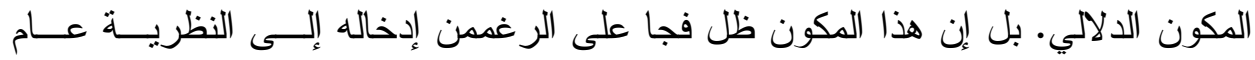

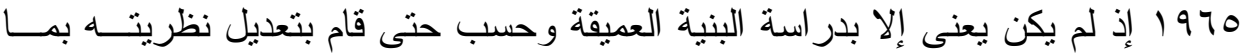

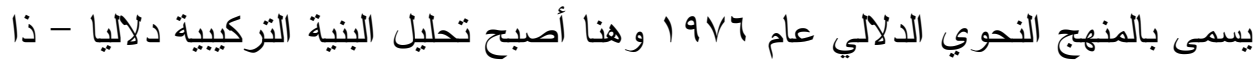
خطر عظيم في النظرية التوليدية. الالالة و المعنى:

يعرف بعضهم علم الدلالة بأنه:" دراسة المعنى أو العلم الذي يدرس المعنى"؟

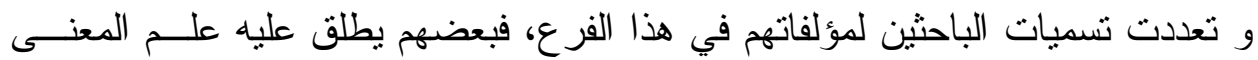

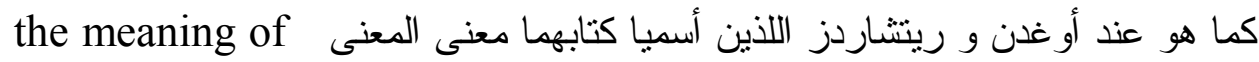
Studies in the science of ( ) ( meaning ) ( meaning هو عند بالمر و بييرجيرو مثنلا. و اضطرب بعض الباحثينفي تحديد مصطلح واحد من إنه هذين المصطلحين ؛ فالاكتور محمد على الخولي يسمي كتابه علم الدلالة ( علم المعنى)

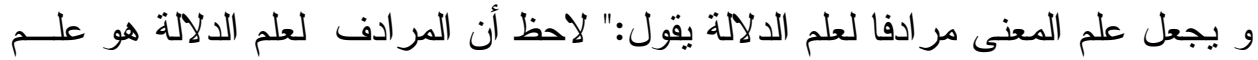

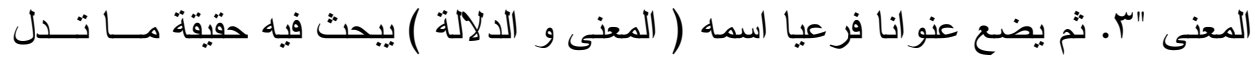

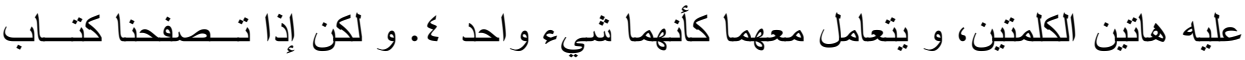

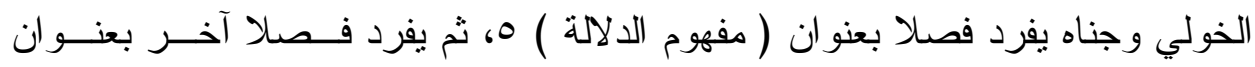

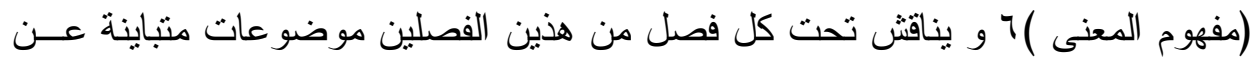

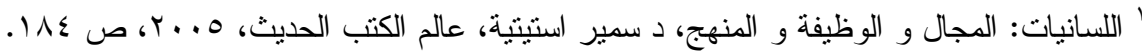

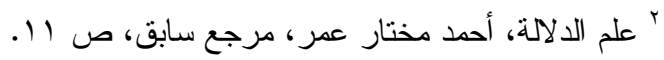

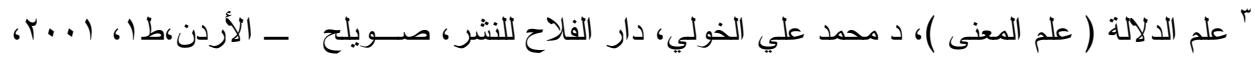
ص س 14

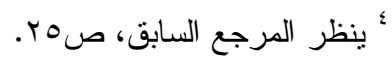

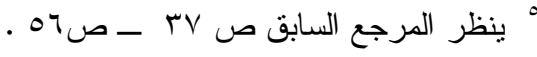

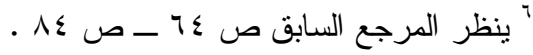


الآخر حتى إن الناظر في الكتاب ليحكم أن المعنى و ما يتعلق به مصطلح آخــر غيـر

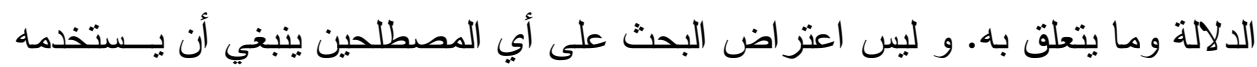

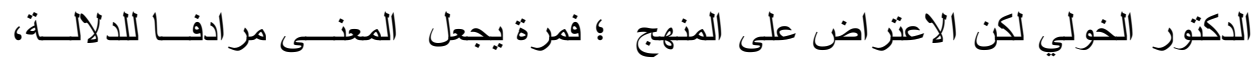

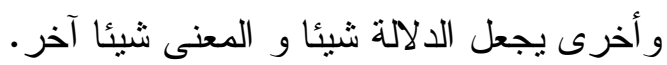

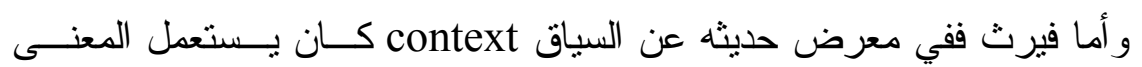

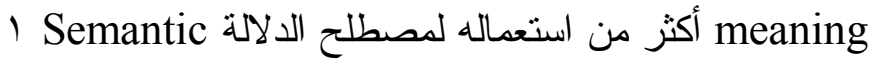
ويقول ستيفن ا،لمان:" و لقد تعرضت الكلمة و وظائفهــا للبحـــث الــدقيق...

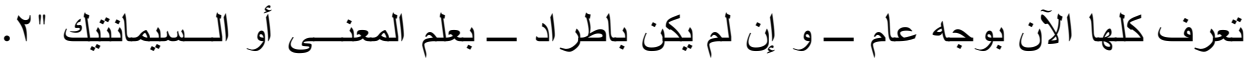

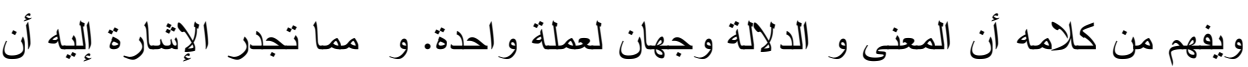
له كتابا آخر اسمه ( علم المعنى ).

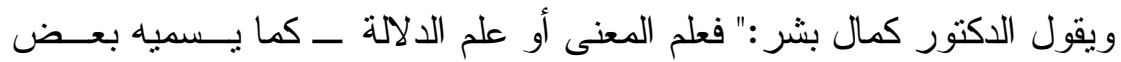

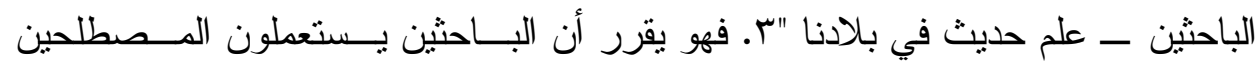

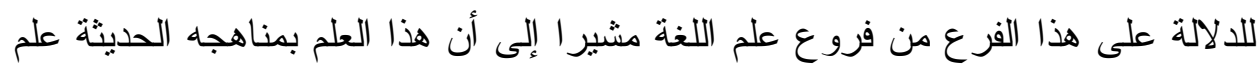
حديث الو لادة.

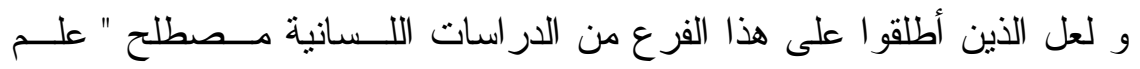

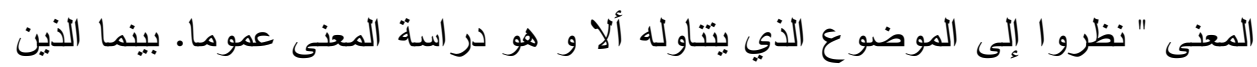

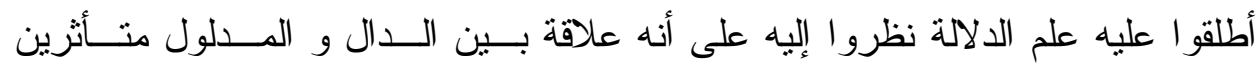
بمصطلحات فرديناند دي سوسير .

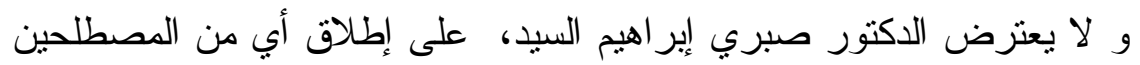

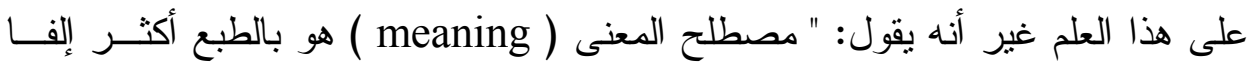

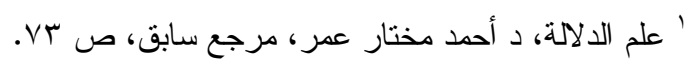

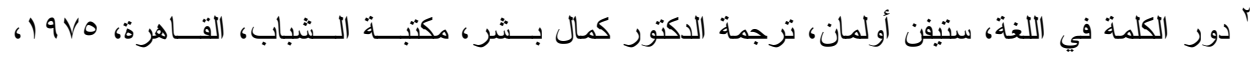

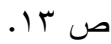

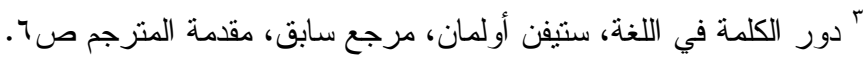

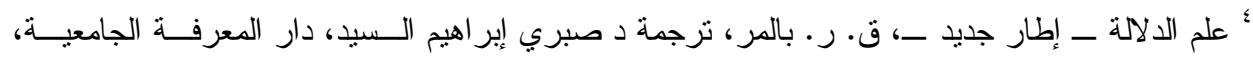

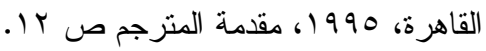


وربما يكون مصطلح المعنى أكثر إلفا لنا فهو مــصطلح عريـق فـي تز اثتــا العربي غير أن هذا اللفظ يحتمل معاني عديدة ؛ لذا فإن البحث يرى أن علم الدلالة خير مصطلح يمكن أن يطلق على هذا العلم. ويقول الدكتور عبدالكريم مجاهد:" كان الاهتمام بدلالة الألفاظ من أجل در اســـة

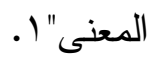
ويفهم من عبارته هذه أن الدلالة ليست هي المعنى بل هي السبيل لفهم المعنى.

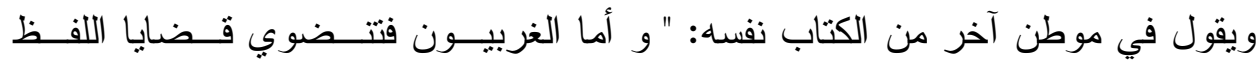

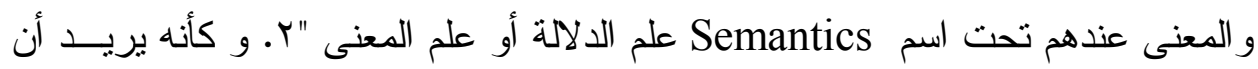

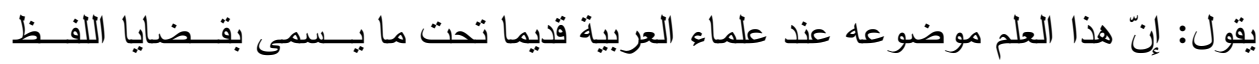

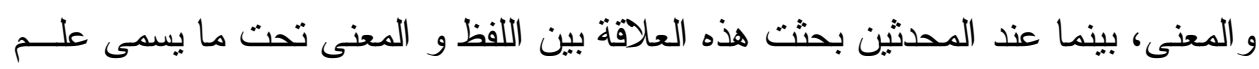

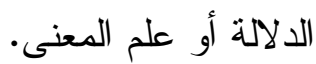

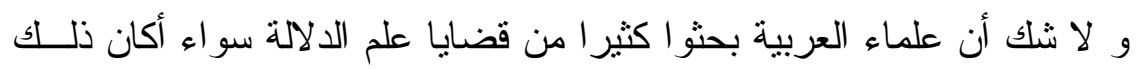
عند اللغويين أم عند البلاغيين و النقاد. و يقف جون لايونز عند الفرق بين المعنى و الدلالة مبينا أنهما مختلفان ؛ فهو

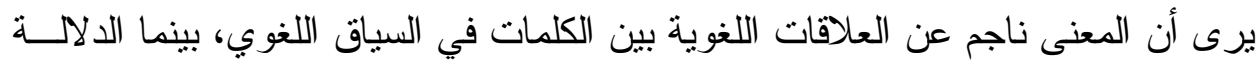

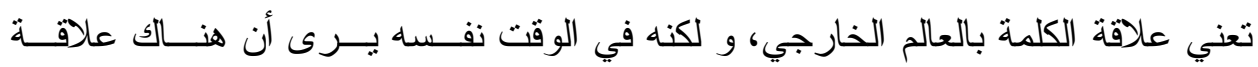

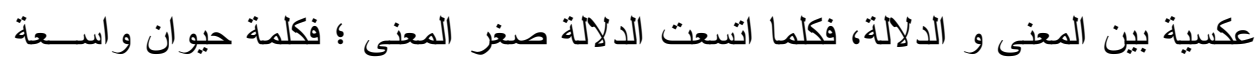

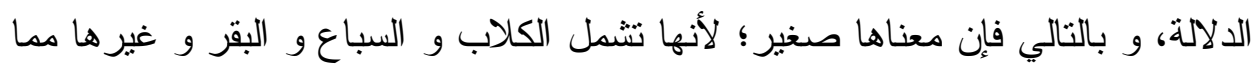

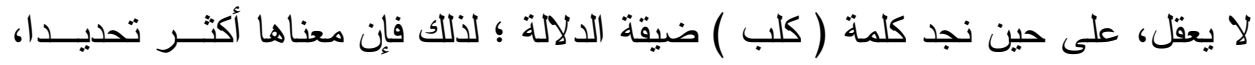

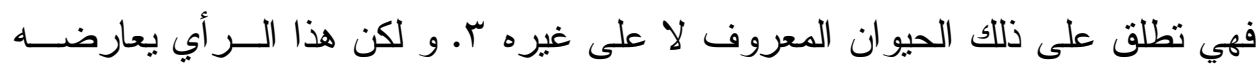

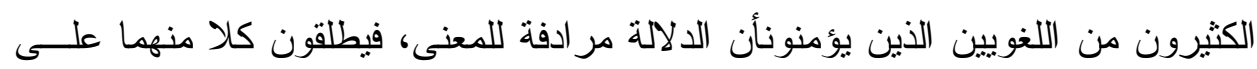

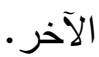

' الدلالة اللغوية عند العرب، د عبدالكريم مجاهد، د.ن، 1910 19، ص صد 9.

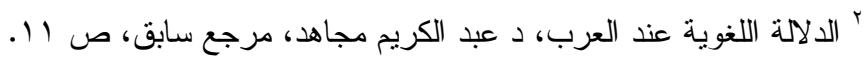

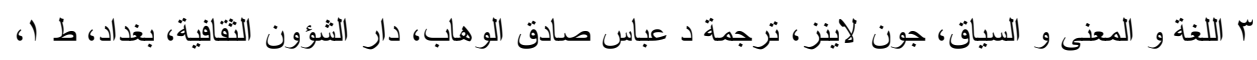

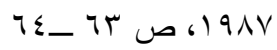


و سيقف البحث عند المفردات التي استعملها الجرجــاني فــي كتابــهـ دلائـلـل

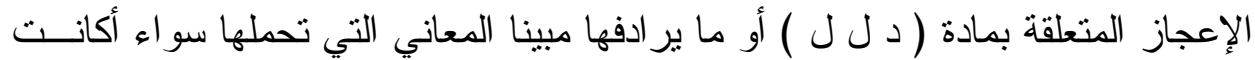

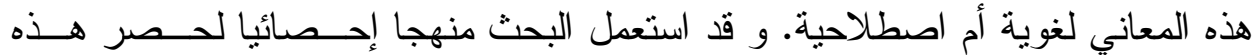
المفردات، ثم تحليلها مستعينا بالمنهج التحليلي. ( بنظر الثكل الآتي )

\begin{tabular}{|c|c|c|c|}
\hline عدد التكرار & الكلمة & عدد التكرار & الكلمة \\
\hline 1. & عنى & $\varepsilon V$ & دلّ" \\
\hline rar & معنى & r & استخل \\
\hline 19 & قصنَ & r & دلالةr \\
\hline$r$. & قصند & ro & دليل \\
\hline IV & مقصود & דr & دال \\
\hline 91 & أر اد & 0 & مدلول \\
\hline vo & مر اد & 7 & استخ لال \\
\hline$\varnothing$ & أوب r & $\varepsilon$ & فسّر \\
\hline 1. & تأويل & 01 & تفسير \\
\hline
\end{tabular}

يتبين من الجدول السابق النتائج الآتية:

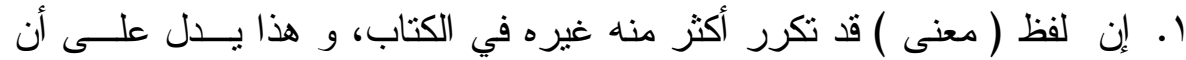
كلمة ( معنى ) كانت أكثر إلفا عند الجرجاني من غيرها.

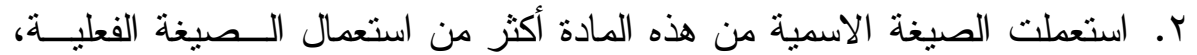
على خلاف مادة دلّ فإن الصيغة الفعلية منها كانت أكثر استعمالا في الكتــاب. و هذا يعني أن الجرجاني يميل إلى استعمال ( معنى ) بدلا من الدالالة، و (دل)

$$
\text { بدلا من عنى. }
$$

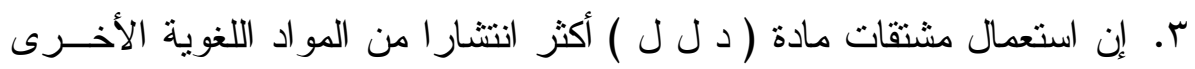

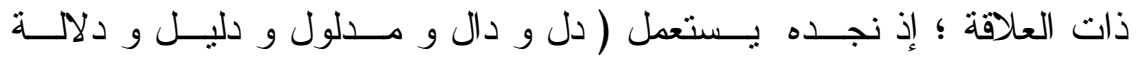

' ' الأفعال الواردة في الجدول آثرت كتابتها بصيغة الماضي و إن ورد بعضها بصيغة المضار ع.

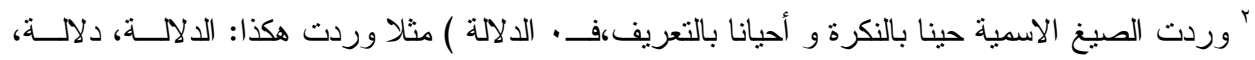

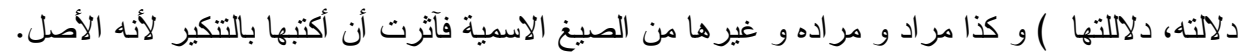

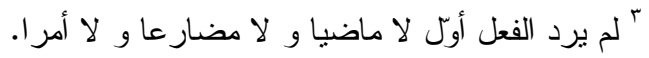


و استدلال، و استثل )، بينما لا نجد هذا الاتتـشار لمـشتقات المـــواد اللغويــة

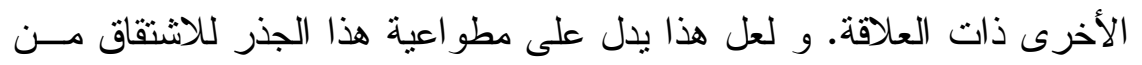

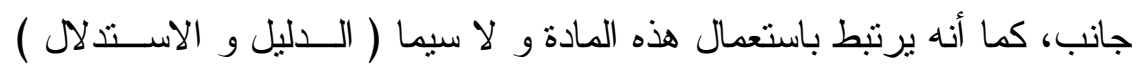

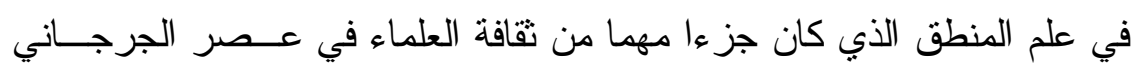

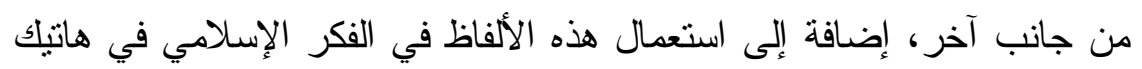

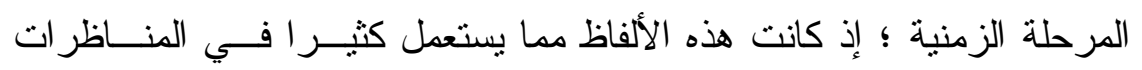

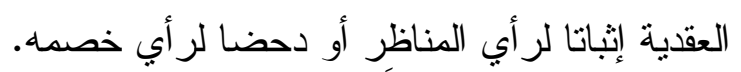

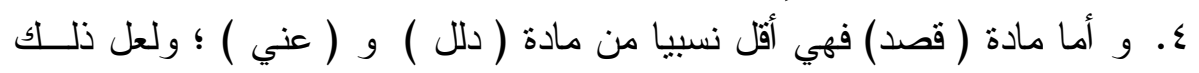

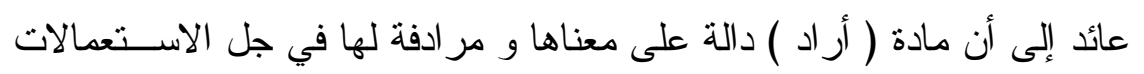
اللغوية لهذه المادة. ه. و تقل مادة ( أول ) في هذا الكتاب، و ربما يعود ذلك إلى أنها مادة ارتبطــــ

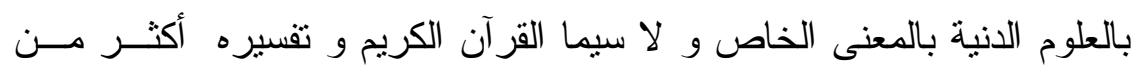
ارنباطها بعلوم اللغة. مادة ( دلل):

جاء في مقاييس اللغة:" الدال و اللام أصلان، أحدهما إبانة الــشيء، بأمســارة

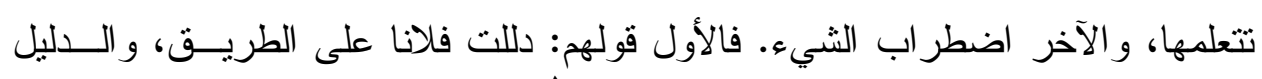

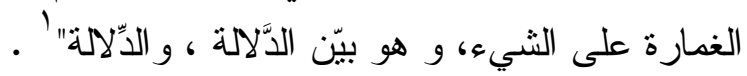
وفي القاموس:" دله عليه دلالة ويتلث ودلولة فئ فاندل سدده إليه و الاليلى كخليفـى

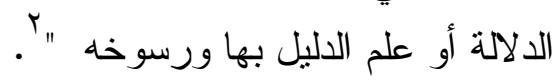

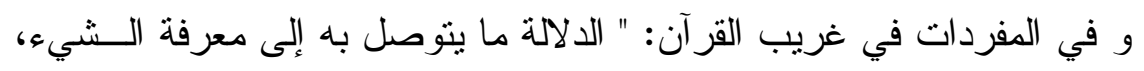

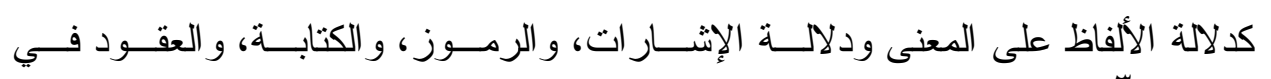

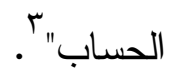

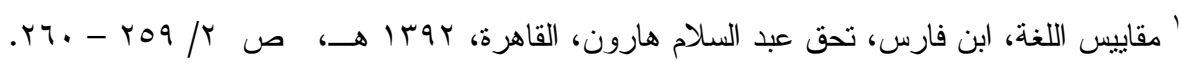

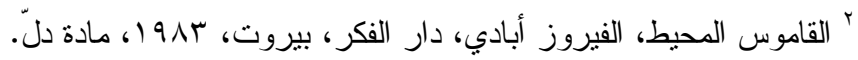

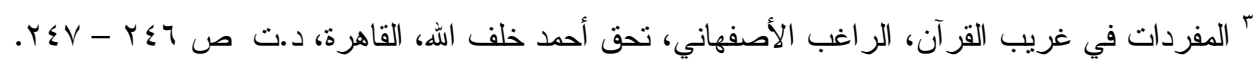




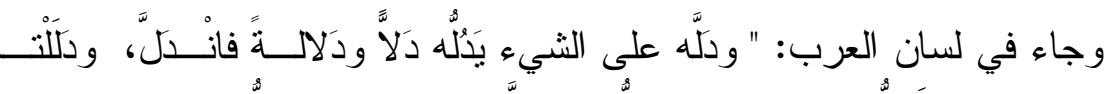

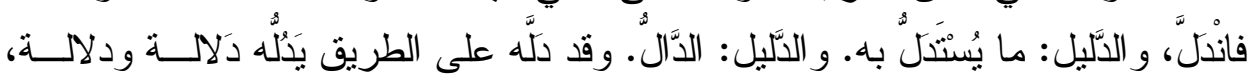

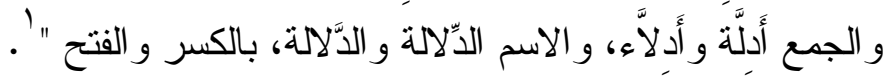

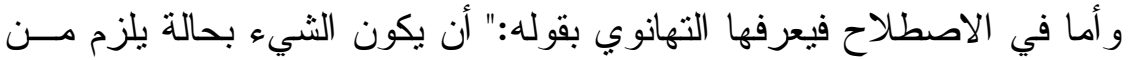

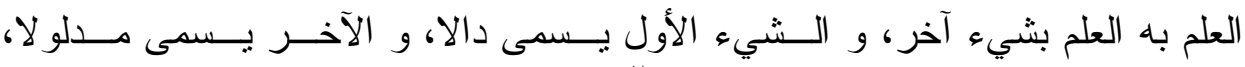

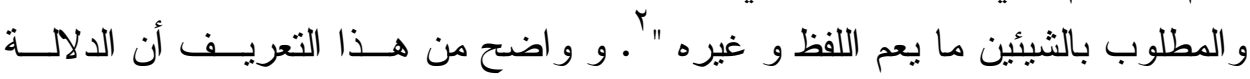

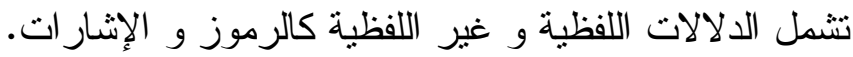

\section{واستعمل الجرجاني الفعل دل لمعان، هي:}

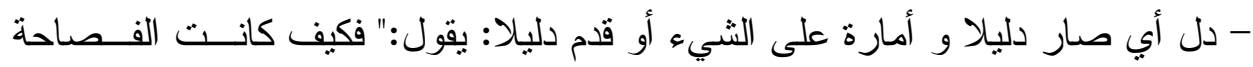

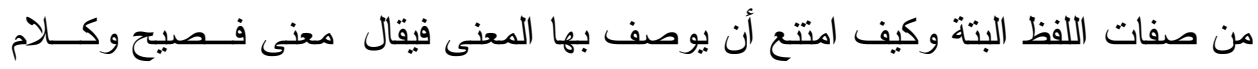

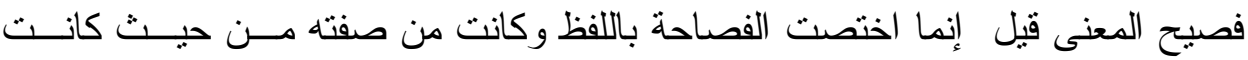

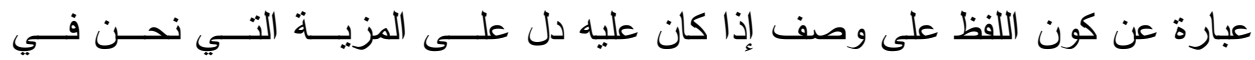

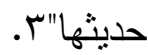

فو اضح أن الجرجاني استعمل دلّ بمعنى الدليل و الأمارة على صفة الفــصاحة

في اللفظ.

ومنه قوله: " قولنا إن معنى كثثر رماد القدر يدل على معنى تفسيره الذي هو

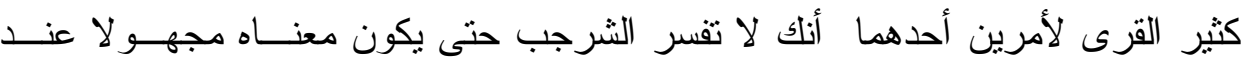

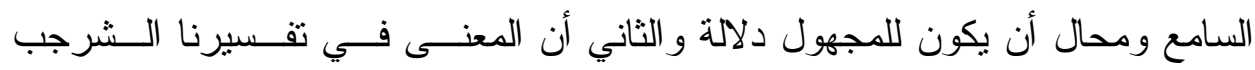

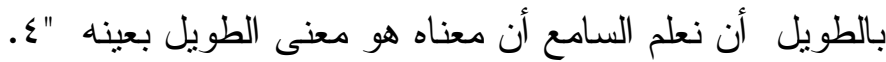

' ل ل ل لسان العرب، ابن منظور ، بيروت، دار صادر ، د.ت، د.ن، مادة دلل.

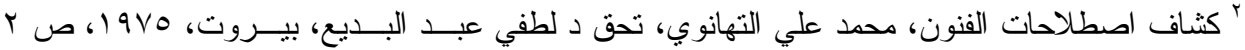

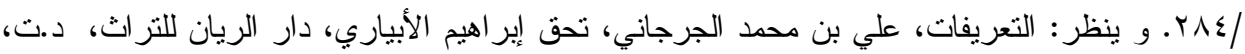

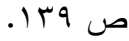

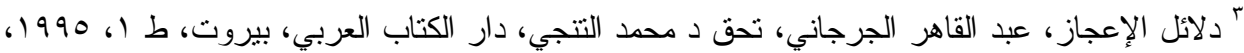


فهو يريد أن كثرة الرماد دليل على كثرة قرى الأضياف.

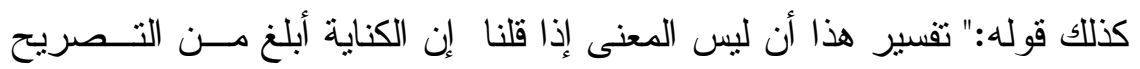

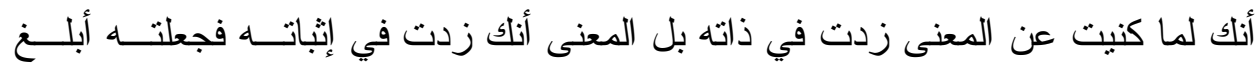

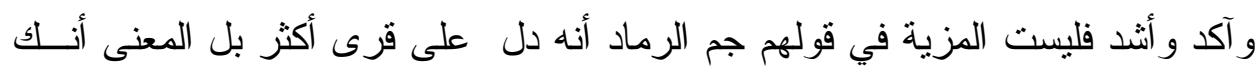

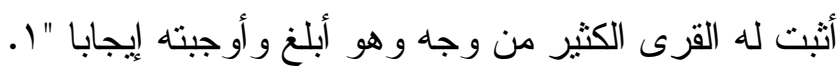

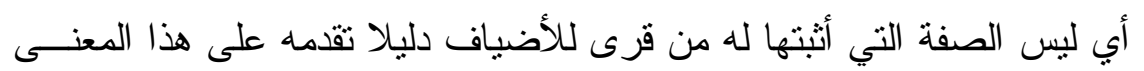
وحسب.

ومن هذا المعنى قوله أيضا : " كمنل أن يحذف خبر المبتدأ أو المبتـــأ إذا دل

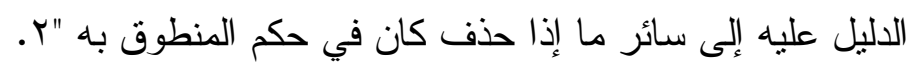

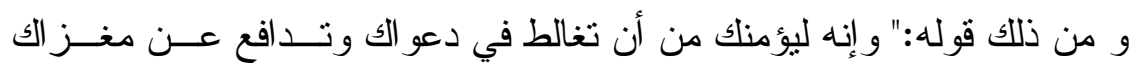

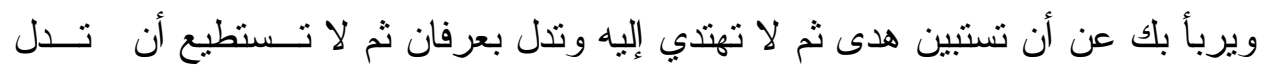

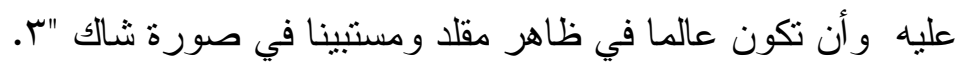

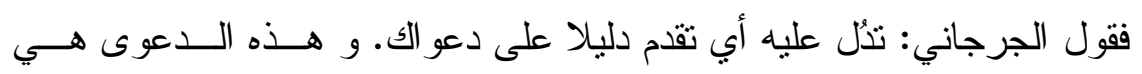
الهدى الذي تبين للك. - يؤدي معناه: كقوله:" ثم إن العجب في أن هذا التعريض الذي ذكرت للك لا يحـــل

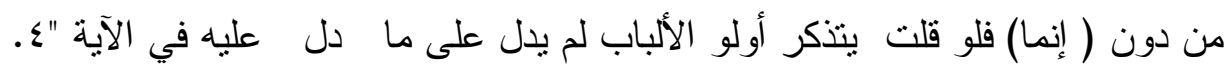

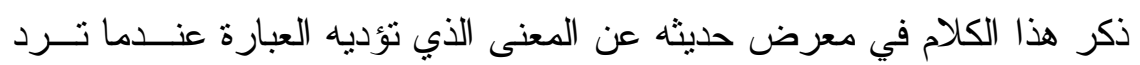

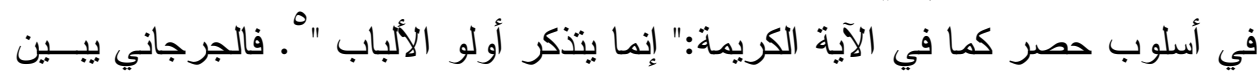

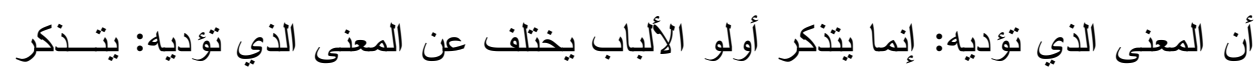
أولو الألباب. دون استعمال أداة الحصر إنما.

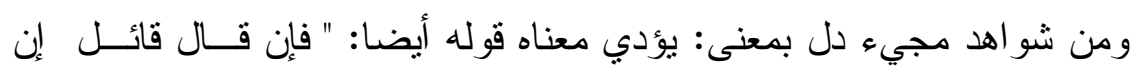

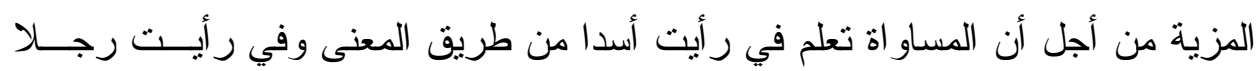

$$
\begin{aligned}
& \text { ' المصدر السابق ص99. }
\end{aligned}
$$

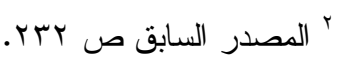

$$
\begin{aligned}
& \text { r المصدر السابق ص المدر المابق صل } \\
& \text { ؛ المصدر السابق • . } \\
& \text { • الر عد } 19 .
\end{aligned}
$$




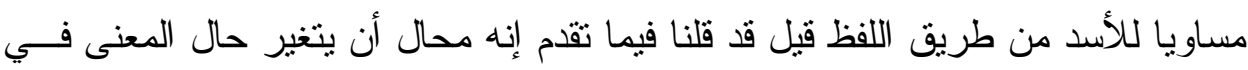

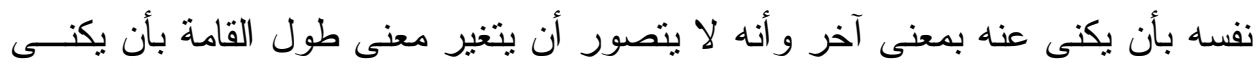

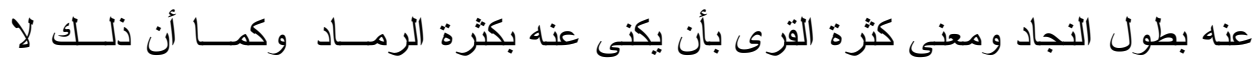

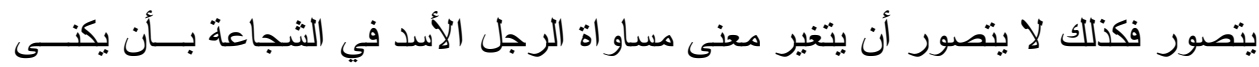

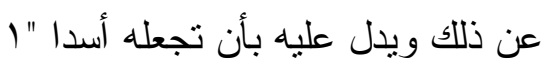

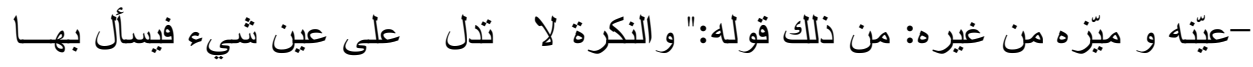

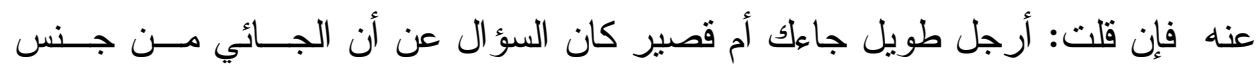

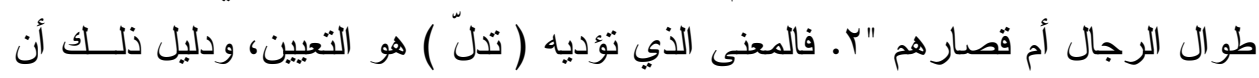

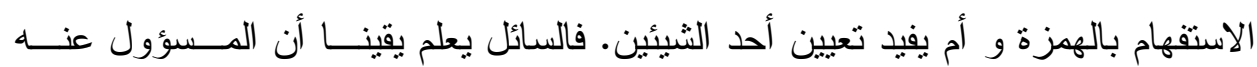

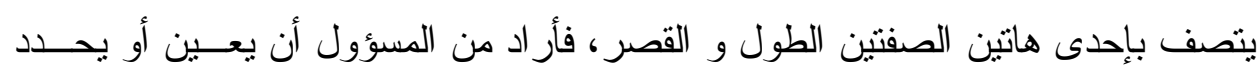

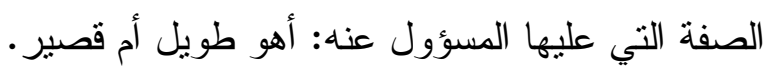

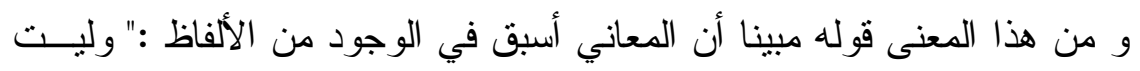

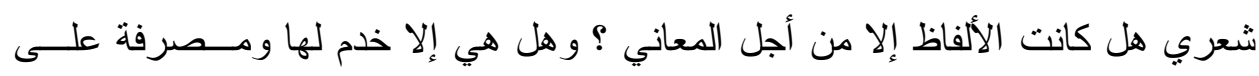

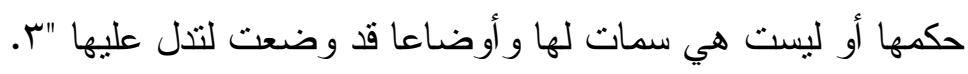

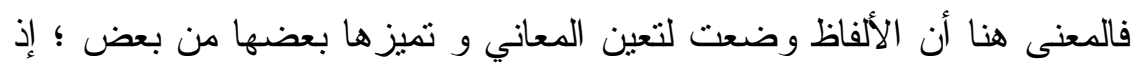

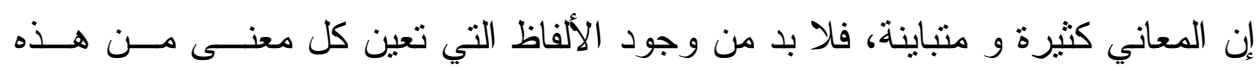

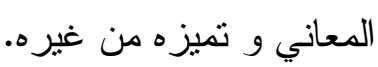

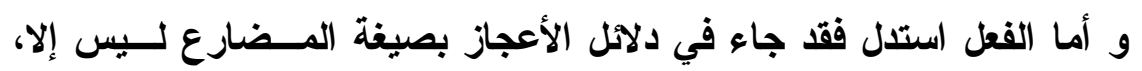
وكان يحمل معنى واحدا فقط هو:

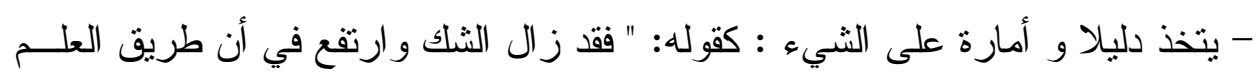

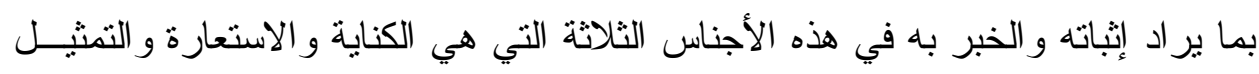

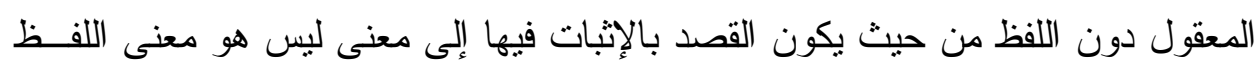

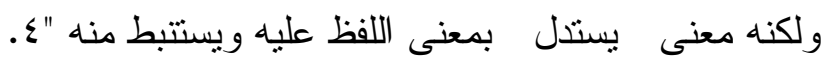

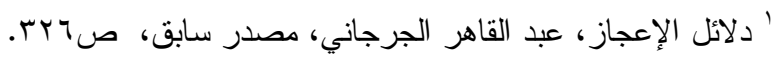

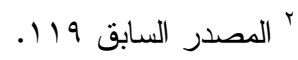

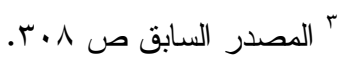

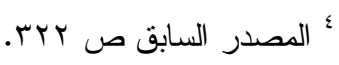


فهو يريد أن يقول: إن الكناية و الاستعارة و التمثيل ليست ألفاظها هـي التـي

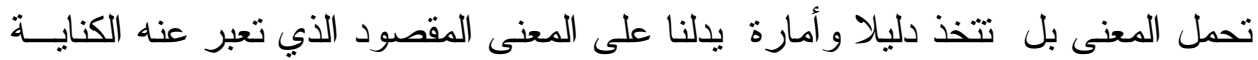

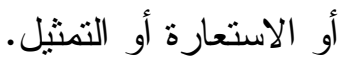

وكقوله في معرض تعليقه على قول الثاعر :

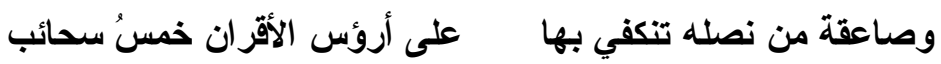

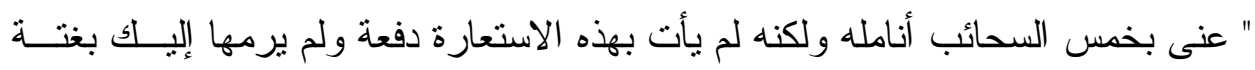

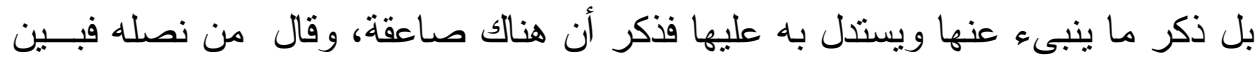

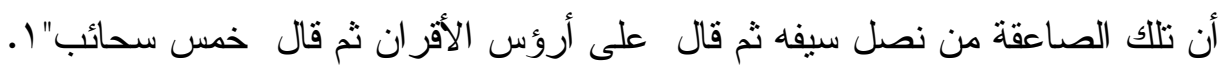

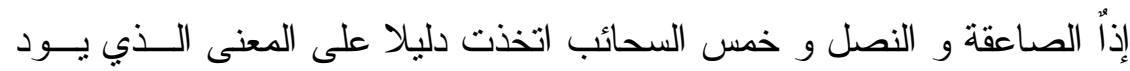

الثاعر تقديمه ألا و هو قوته العظيمة في منازلة الفرسان الثجعان في ساح الوغى. و نرد كلمة( دلالة ) في دلائل الإعجازتحمل المعاني الآتية:

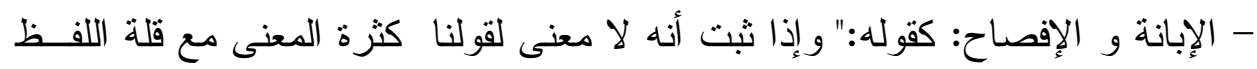

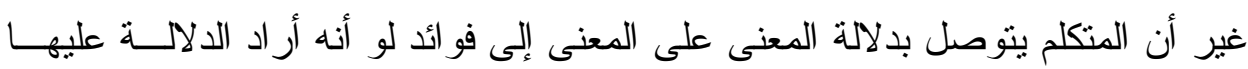
باللفظ لاحتاج إلى لفظ كثير "r.

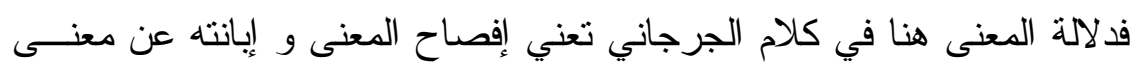

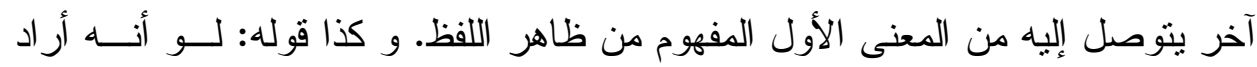
الدلالة عليها أي الإفصاح عنها و إبانتها باستعمال الألفاظ التي تجليها.

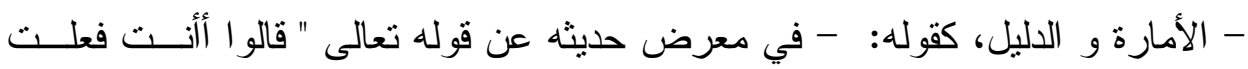

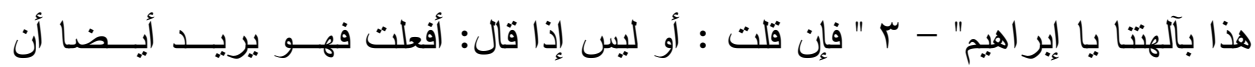

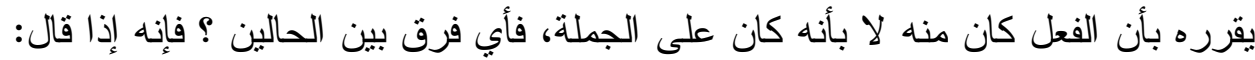

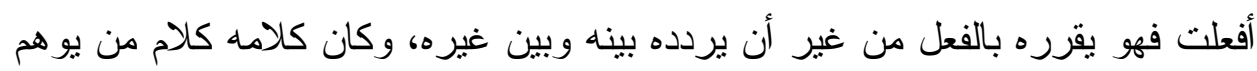

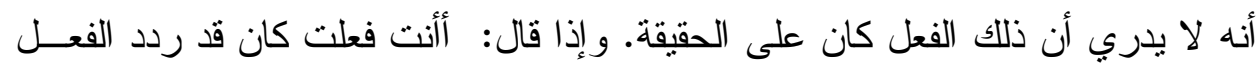

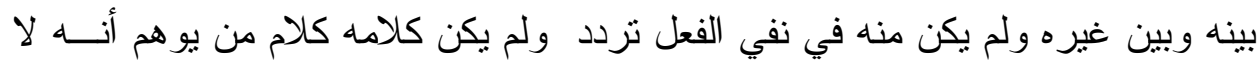

$$
\begin{aligned}
& \text { ' 'المصدر السابق ص • •rr. }
\end{aligned}
$$

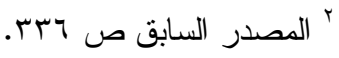

$$
\begin{aligned}
& \text { r الأنبياء rاء }
\end{aligned}
$$


يدري أكان الفعل أم لم يكن بدلالة أنك تقول ذلك و الفعل ظاهر موجود مشار إليه كـــا

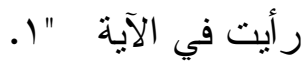

فـــ (دلالة ) هنا تعني أمارة على الثيء. وهذا المعنى لم يذكره صاحب اللسان

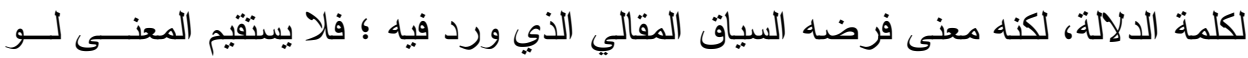
حمل لفظ ( دلالة ) على غير هذا المعنى الذي أثتبته البحث له. لهان. وفي هذا المعنى أيضا استعملت الدلالة في قوله - في معرض الفئ حديثه عن قول

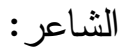

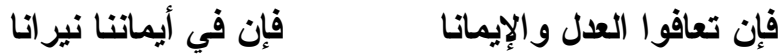

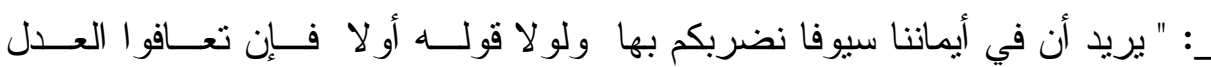

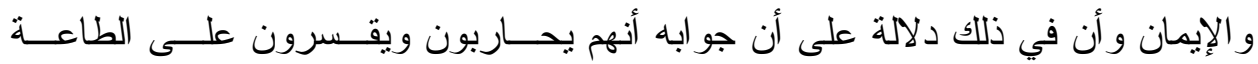

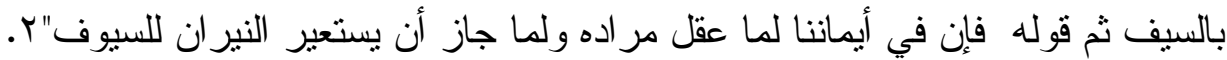

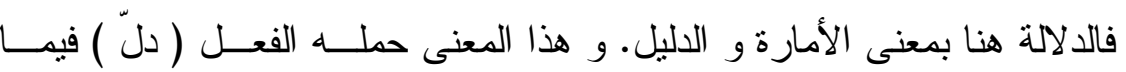

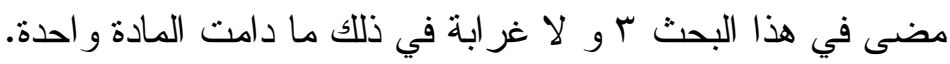

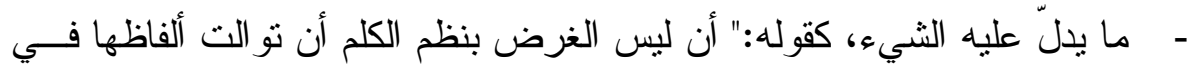

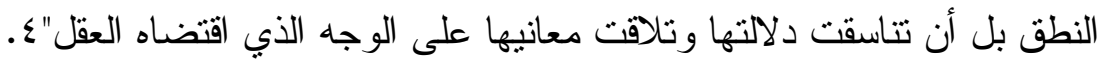
فـلالتها هنا تعني ما تدل عليه.

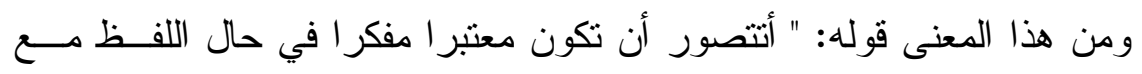

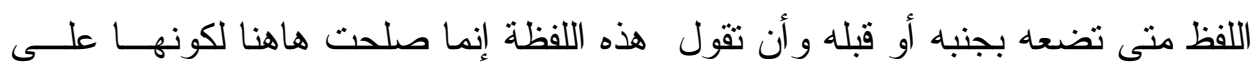

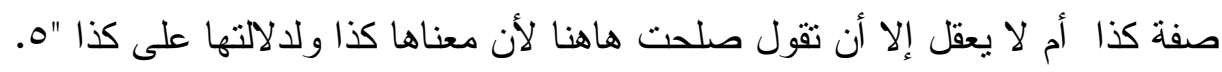

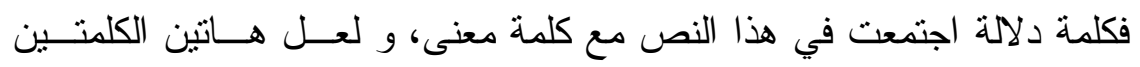

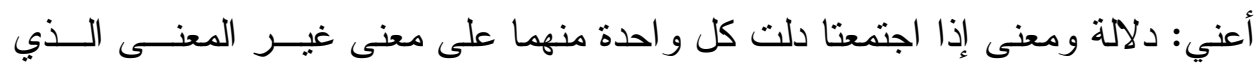

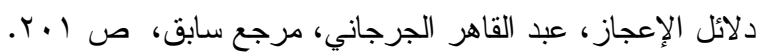

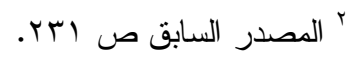
“ بنظر ص r من هذا البحث.

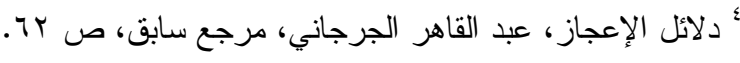

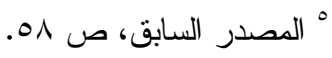




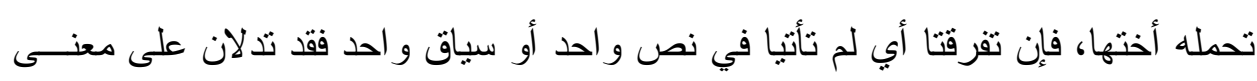

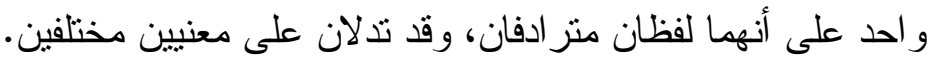

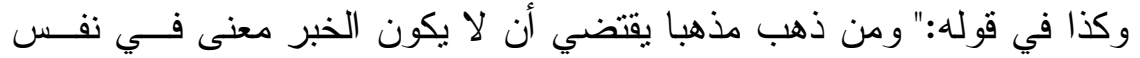

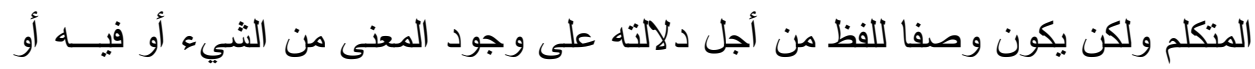

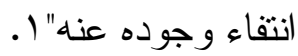

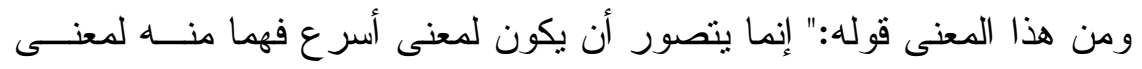

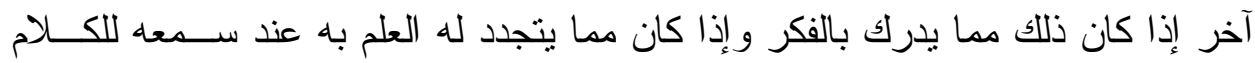

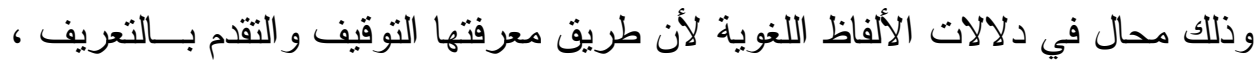

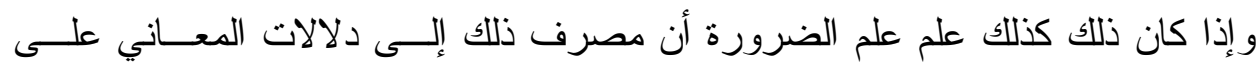

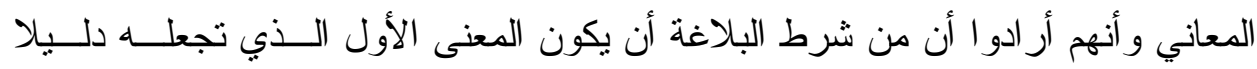

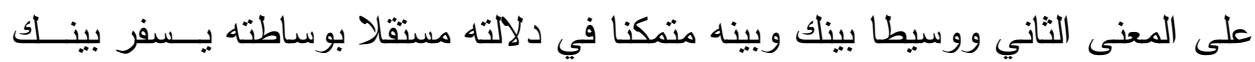

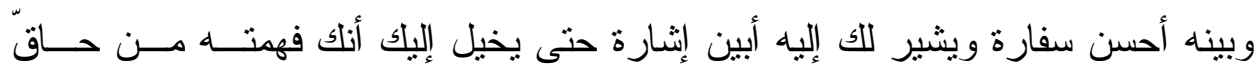
اللفظ وذللك لقلة الكلفة فيه عليك وسرعة وصوله إليك فكان من الكناية مثل قوله "Y.

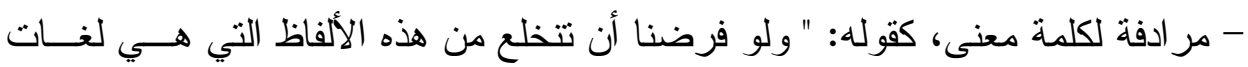

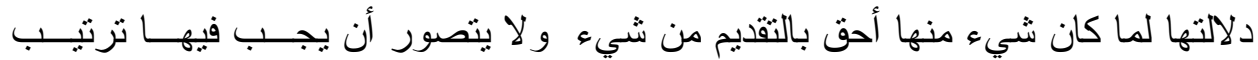

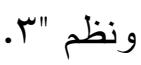

فدلالتها هنا بمعنى معناها الذي تحمله أو تعبر عنه. و أما لفظ ( الاليل ) فيأتي للمعاني الآتية:

- ما يستدل به، وهذا المعنى لهذه المفردة هو معنى لغويّ ذكرته معــاجم اللغـــة.

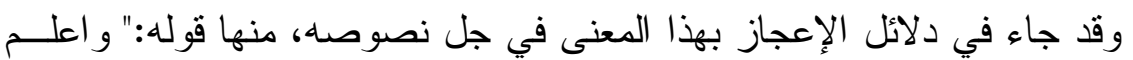

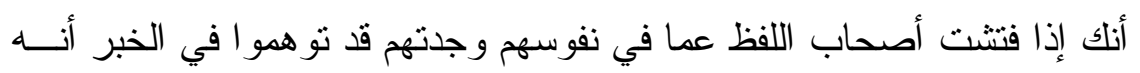

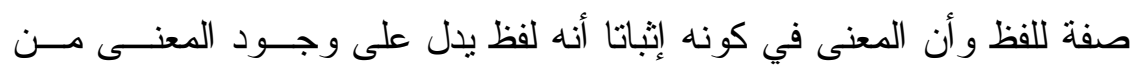

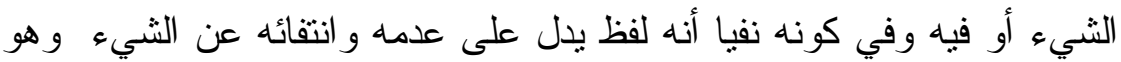

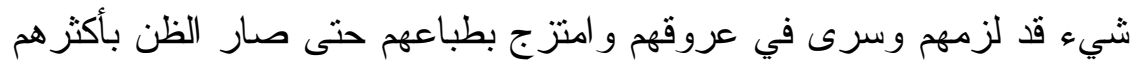

$$
\begin{aligned}
& \text { ' المصدر السابق، ص 01یr. }
\end{aligned}
$$

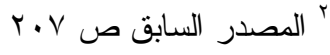

$$
\begin{aligned}
& \text { r المصدر السابق، ص }
\end{aligned}
$$


أن القول لا ينجع فيهم و الدليل على بطلان ما اعتقدوه أنه محـــال أن يكــون اللفظ قد نصب دليلا على شيء ثم لا يحصل منه العلم بذلك الثيء ". فقد وردت الدليل في النص السابق مرتين مرة معرفة، و مرة نكرة، و هي في لهي لهي الحالتين تحمل معنى و احدا هو ما يستخل به. وبهذا المعنى جاءت هذه اللفظة في قوله: " وذاك أن الألفاظ أدلة على المعاني بله بله وليس للاليل إلا أن يعلمك الثيء على ما يكون عليه "r.

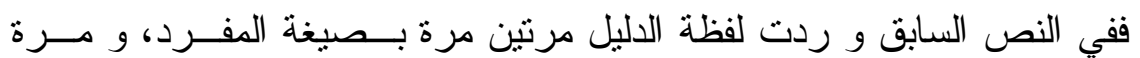
بصيغة الجمع، و هي تعني ما يستدل به، بل بين الجرجاني الوظبفة التي يؤديها الاليل، ألا وهي: أنه يخبرك الثيء عله و هلى أي صفة يكون.

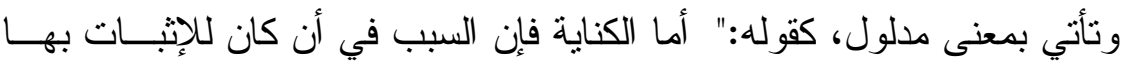

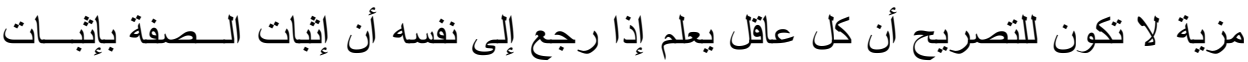

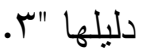

أي بإثبات مدلولها أي ما دلت عليه.

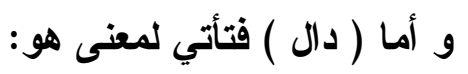

- ما يدل عليه اللفظ من معنى، كقوله: " إن الألفاظ إذا كانت أوعية للمعاني فإنها

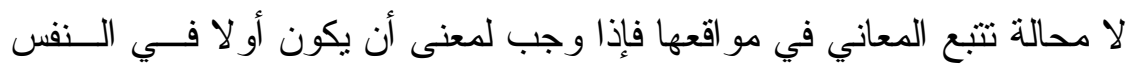

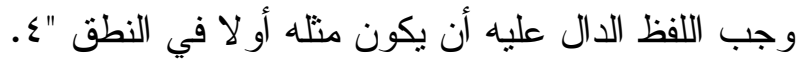
فالجرجاني استعمل لفظ الدال استعمالا اصطلاحيا كما يستعطله المحدثون مسن علماء الدلالة، إذ عدّ اللفظ دالا و المعنى مدلو لا عليه.

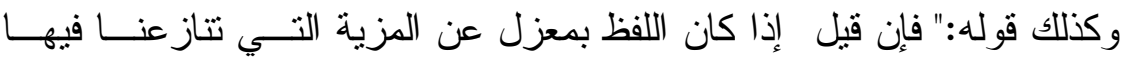

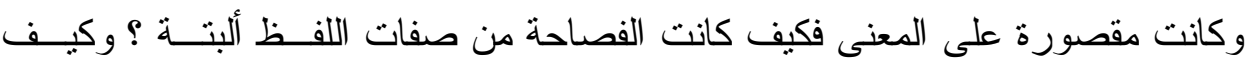

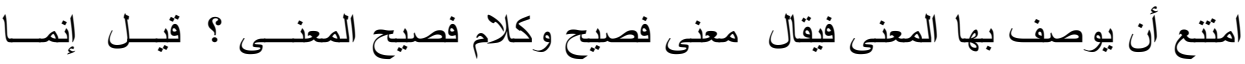
اختصت الفصاحة باللفظ وكانت من صفته من حيث كانت عبارة عن كون اللفظ علــى بـى

$$
\begin{aligned}
& \text { ' المصدر السابق ص ع بـ. }
\end{aligned}
$$

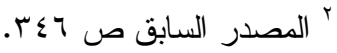

$$
\begin{aligned}
& \text { " المصدر السابق ص • V. }
\end{aligned}
$$

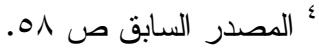




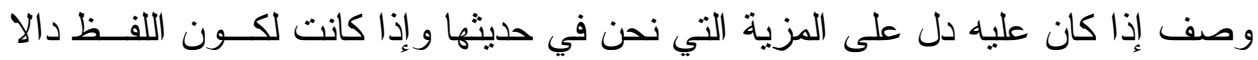

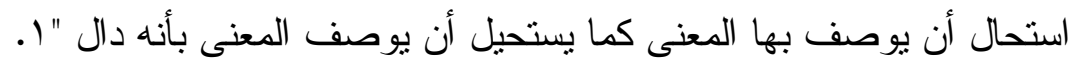

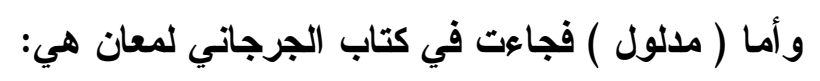

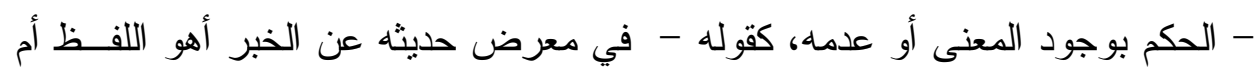

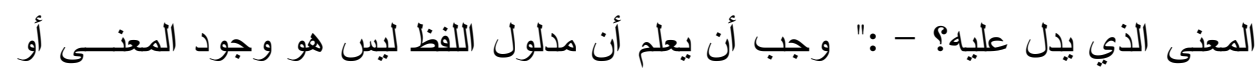

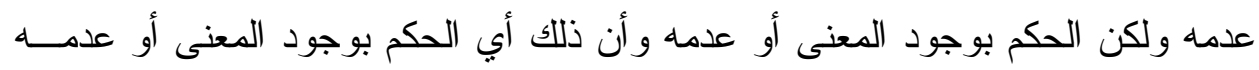

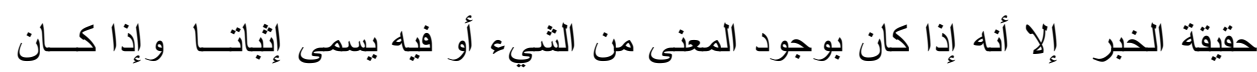

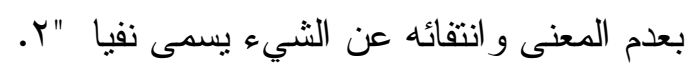
فقد بين الجرجاني أن الخبر في الجملة الاسمية ليس هو ما يدل فئل عليه اللفظ من معنى بل هو الحكم بوجود هذا المعنى أو عدم وجوده.

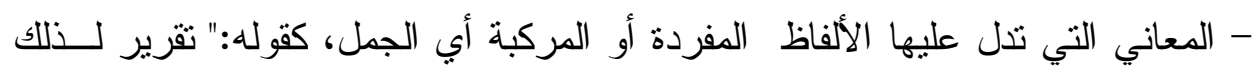

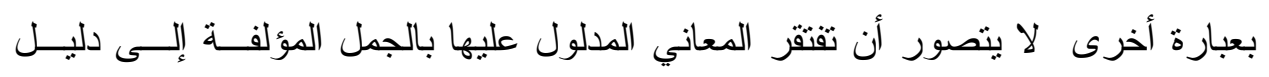

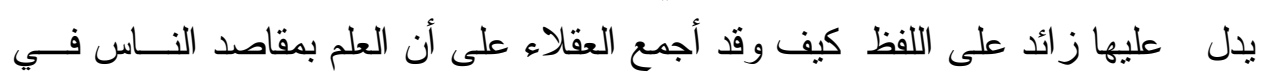

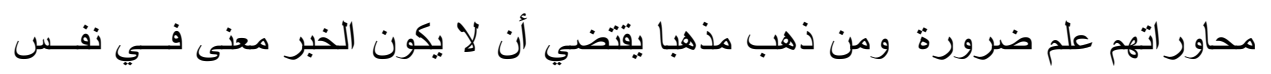

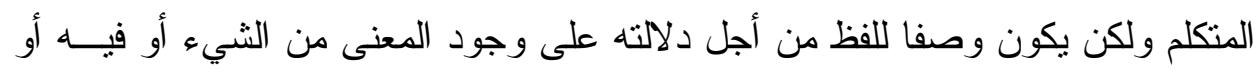
انتفاء وجوده عنه كان قد نقض منه الأصل الذي قدمناه من حيث يكون قد جعل دلالته المعنى

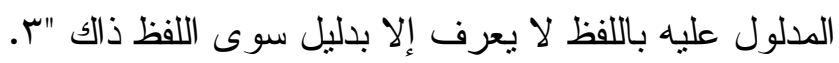

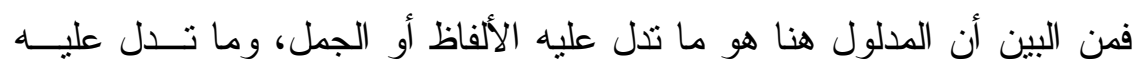

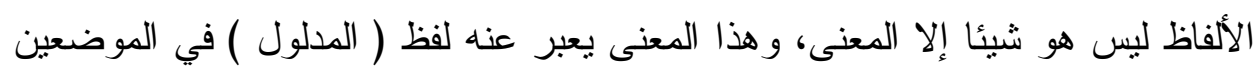

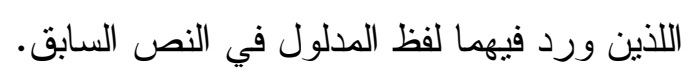

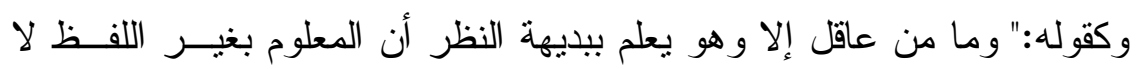
يكون مدلول اللفظ " "؟.

$$
\begin{aligned}
& \text { ' 'المصدر السابق ص ع 7. } \\
& \text { r المصدر السابق ص ع^ب }
\end{aligned}
$$

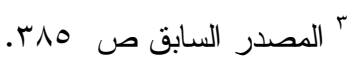

$$
\begin{aligned}
& \text { ؛ المصدر السابق ص میمب. }
\end{aligned}
$$


فقق بين الجرجاني أن المدلول هو المعنى الذي يدل عليه اللفظ، بـل لا معنـى

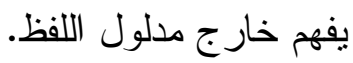

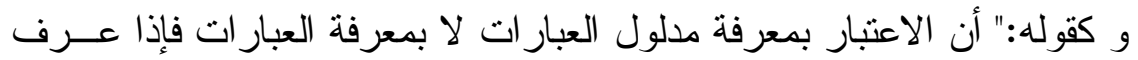

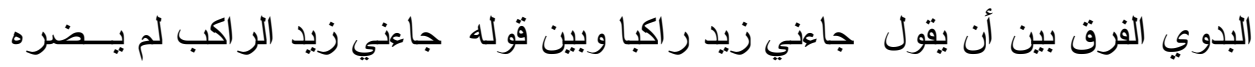

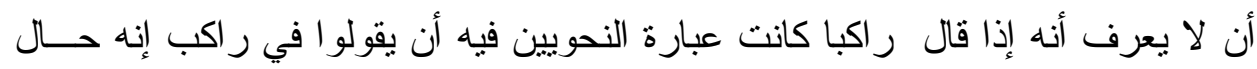

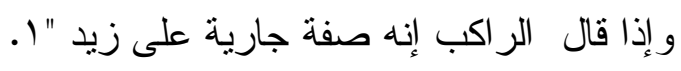

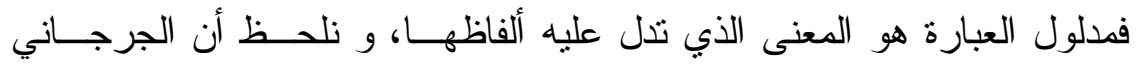

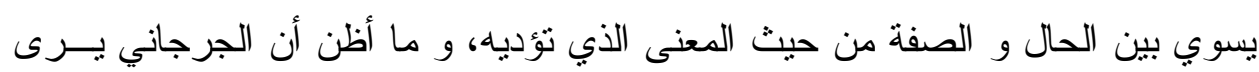
أن التركيين ( جاء زيد ر اكباو جاء زيد الر اكب ) متساويان في المعنى تمام المسـساوة،

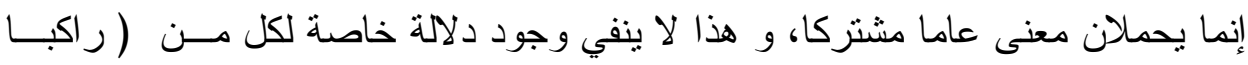

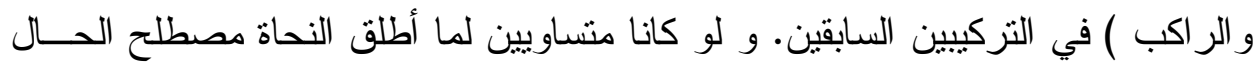

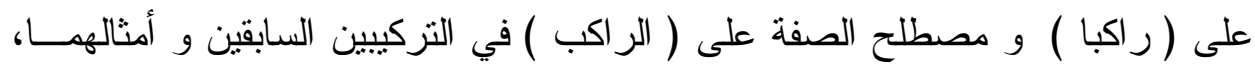

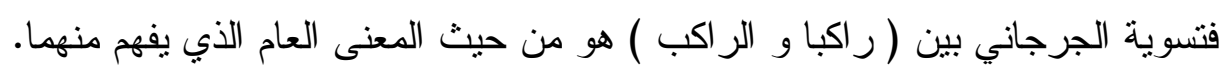

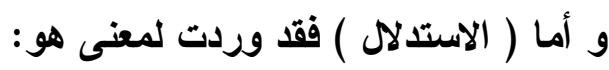

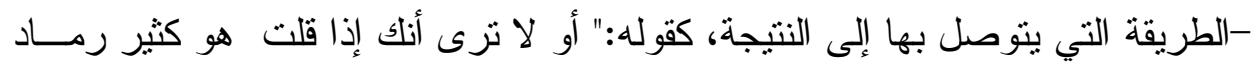

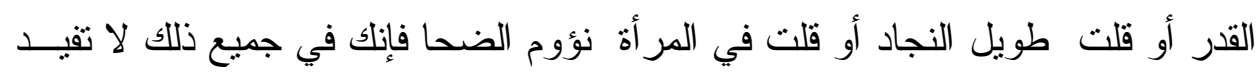

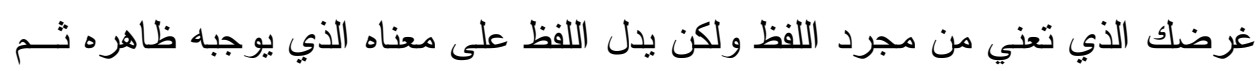

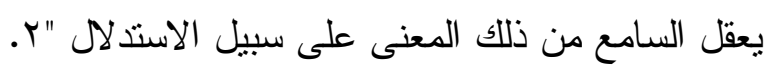

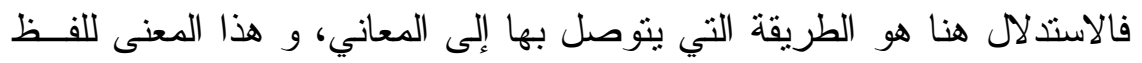

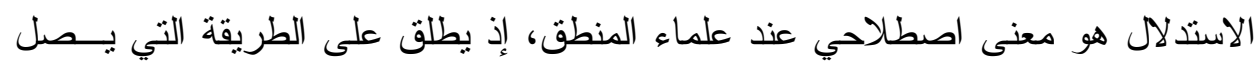

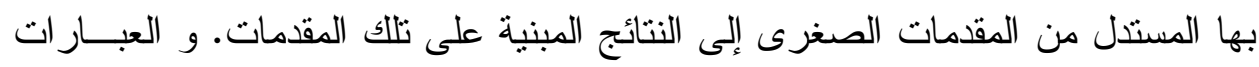
التي ذكرها الجاحظ في النص السابق من مثل ( نؤوم الضحى ) هي كنايات عن معسان الضـان

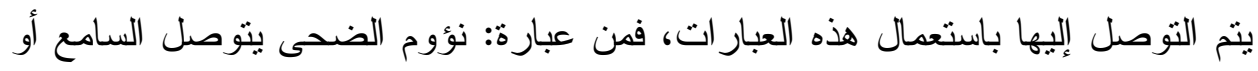

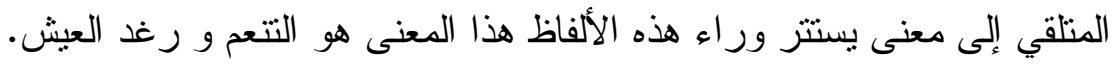

$$
\begin{aligned}
& \text { ' المصدر السابق ص ^ •r". } \\
& \text { r المصدر السابق ص r r.r. r. r. }
\end{aligned}
$$




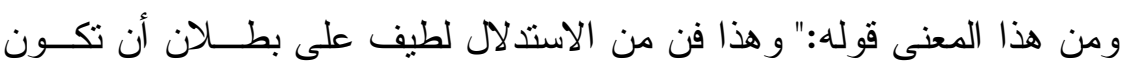

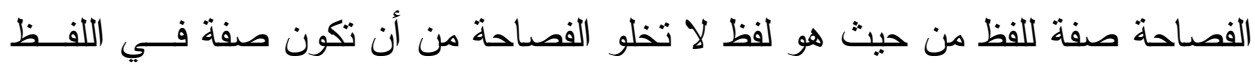
محسوسة تدرك بالسمع أو تكون صفة فيه معقولة تعرف بالقلب فمحال أن تكون صــفة كونة

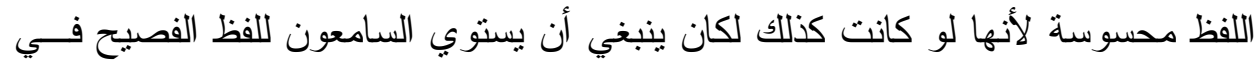

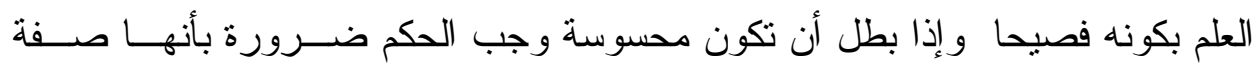

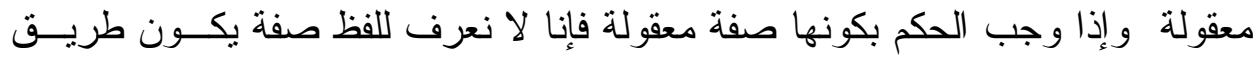

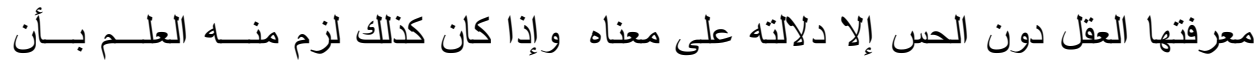

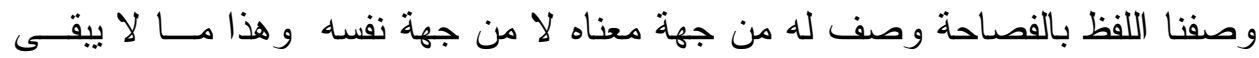
لعاقل معهه عذر في الثلك " (.

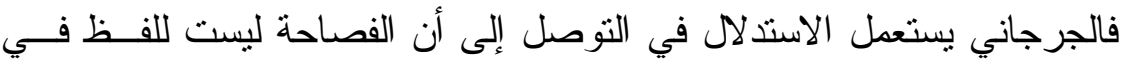

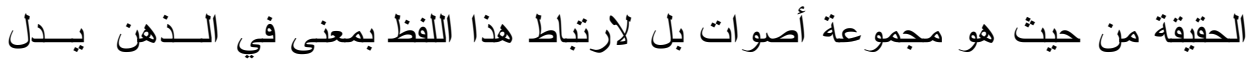

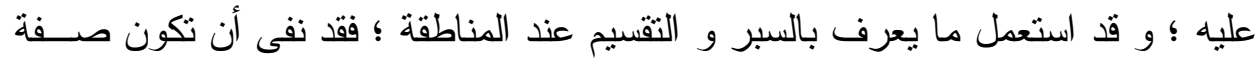

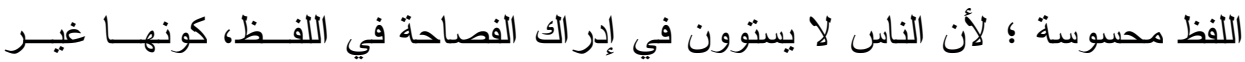

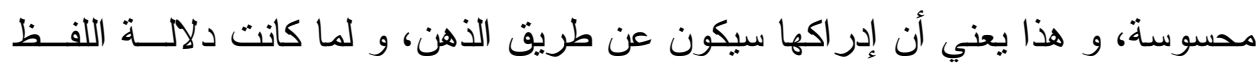

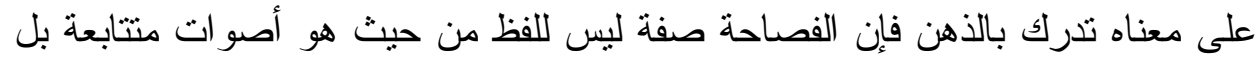
للمعنى الذي يدل عليه اللفظ.

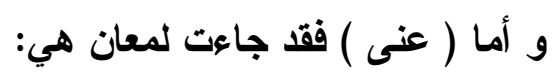

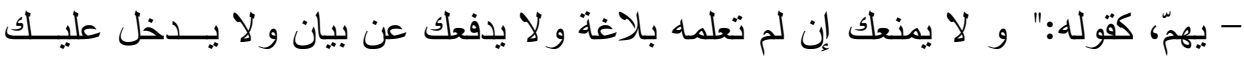

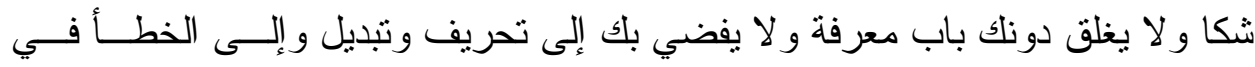

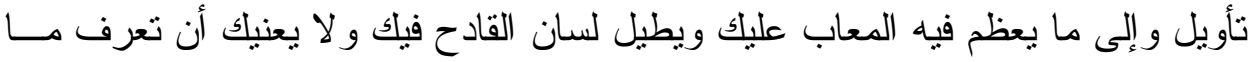
إذا جهلته عرضت نفسك لكل ذللك" ب.

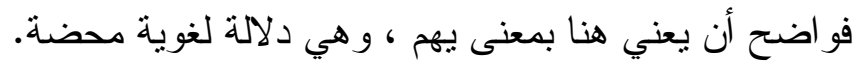

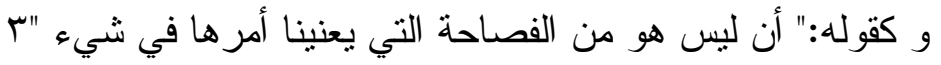

$$
\begin{aligned}
& \text { ' المصدر السابق ص 1 ـr. } \\
& \text { r المصدر السابق ص 9199-9 . }
\end{aligned}
$$

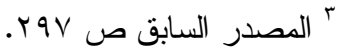




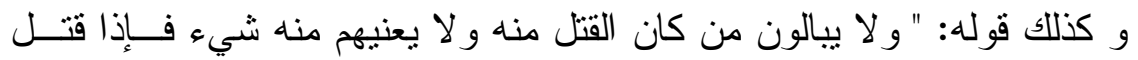

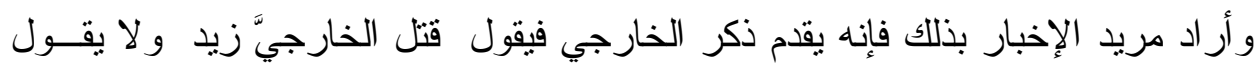

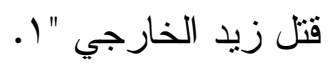

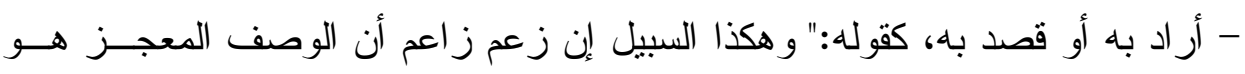

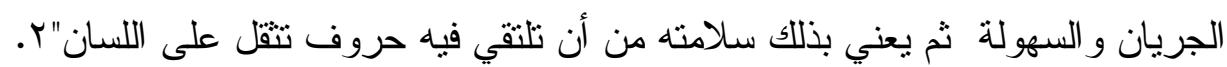

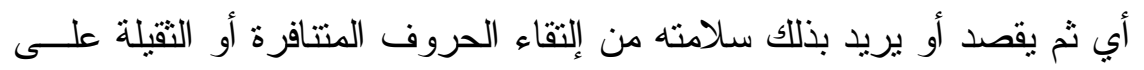

اللسان.

وأما ( معنى ) فقد دلت على المعاني الآتية:

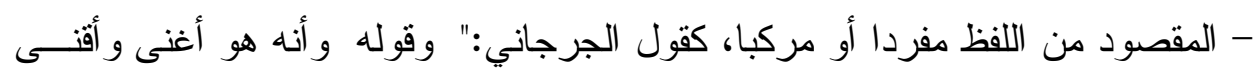

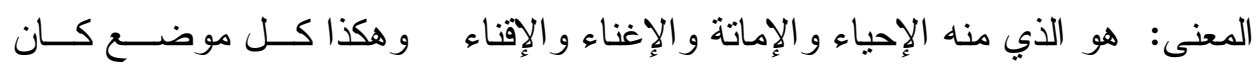

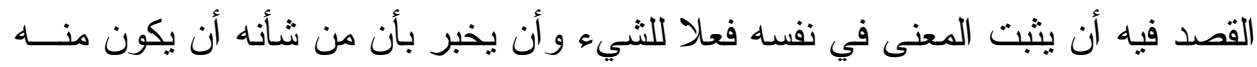

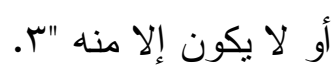

فالمعنى هنا الوارد في كلام الجلرجاني هو مقصود اللفظ.

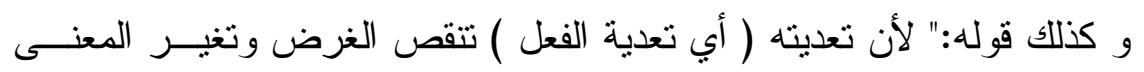

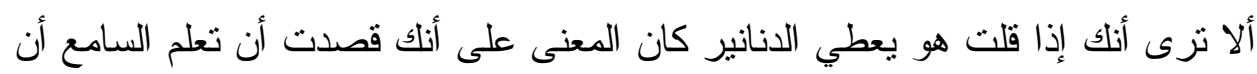

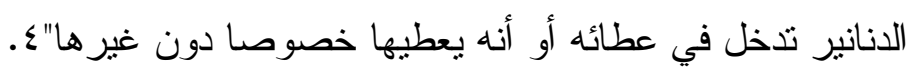

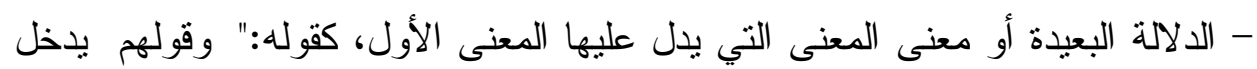

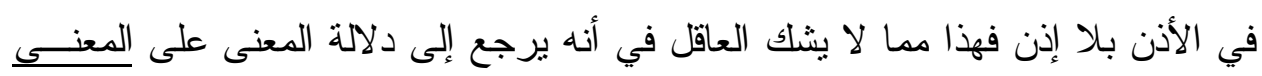

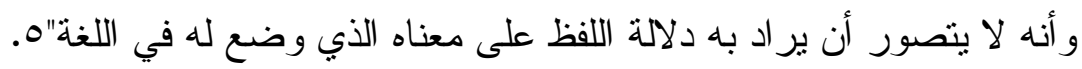

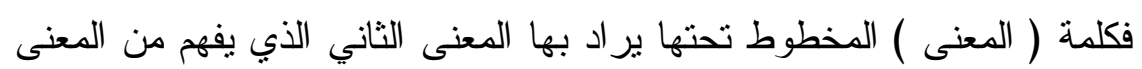
الأول الذي دل عليه ظاهر الكلام.

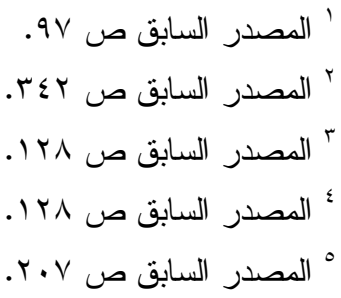


و أما ( قصنَ ) فقل جاعت لمعنى واحد هو:

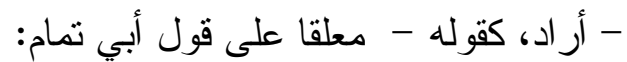

خلت حقب حرس لله وهو حائك إذا الغيث غادى نسجه خلت أنه

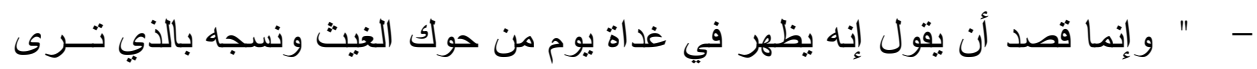

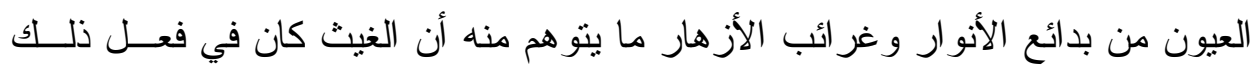

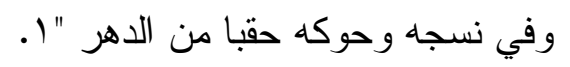
فقصد هنا في كلام الجرجاني تعني أر اد.

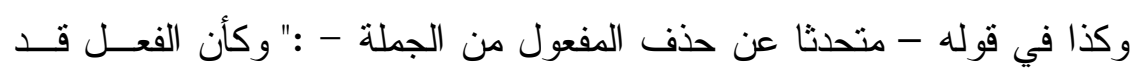

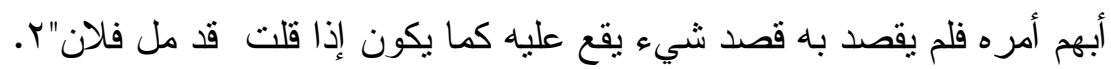

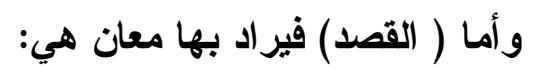
- الإر ادة و المقصود، كقوله:" يتحصل و وجملة الأمر أنه لا يكون ترتيب في شــيء

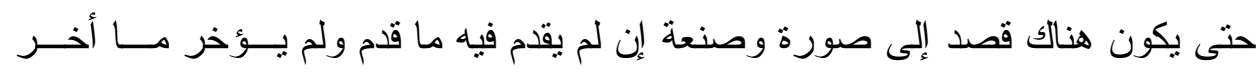

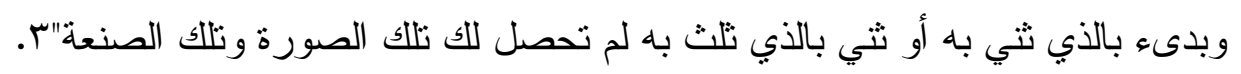

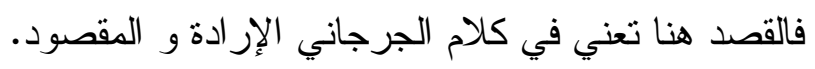

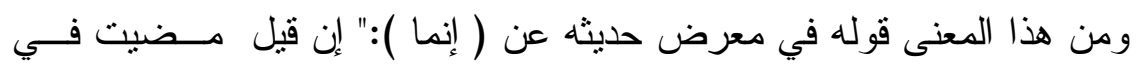

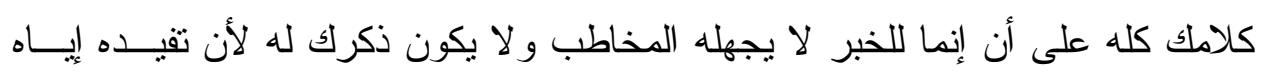

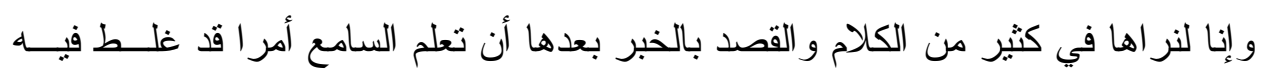

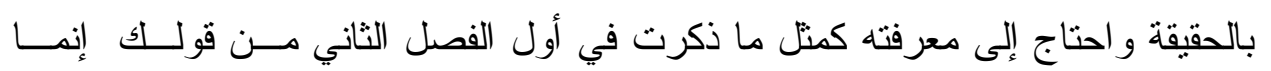

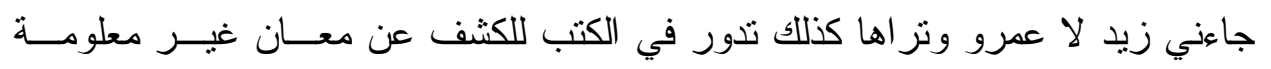

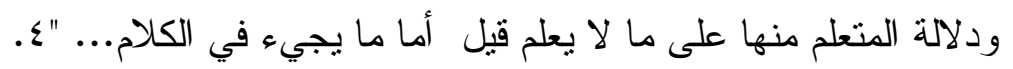

$$
\begin{aligned}
& \text { ' المصدر السابق ص . . ع. } \\
& \text { r المصدر السابق ص • بـ ا. }
\end{aligned}
$$

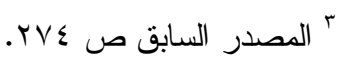

$$
\begin{aligned}
& \text { ؛ المصدر السابق ص r r r. }
\end{aligned}
$$


- يهدف إليه ويعنيه، كقوله:" أعلم أن سبيلك أو لا أن تعلم أن ليست المزية التي تثبتهــا

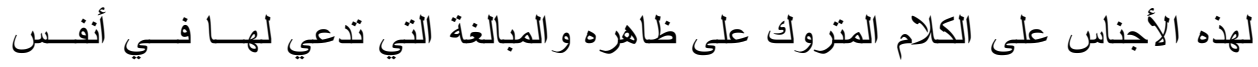

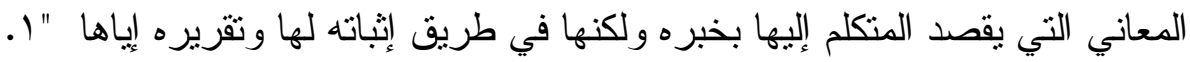

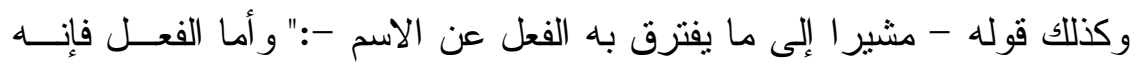

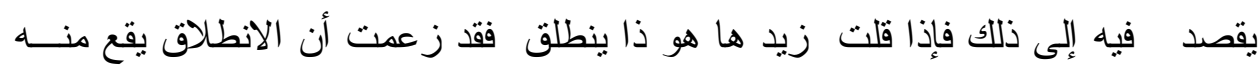

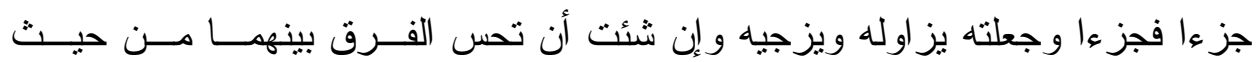
يلطف"ז.

\section{و أما ( مقصود ) فقد حاعت لمعنى هو:}

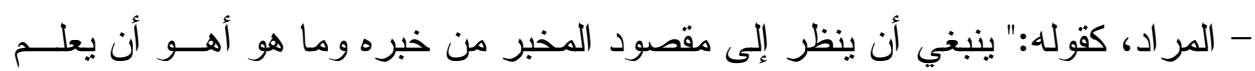

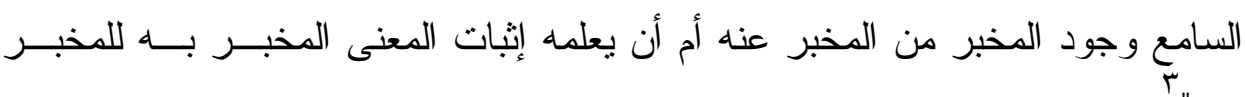
عنه "r. ومنه قوله:" فإن قيل إن المقصود إعلامه السامع وجود المعنى مــن المخبــر

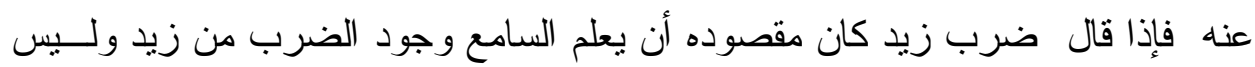

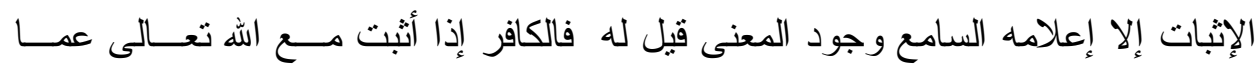

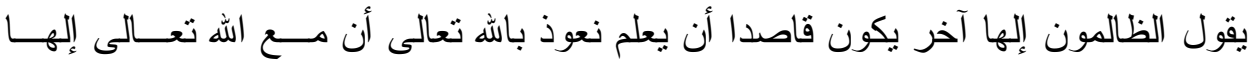

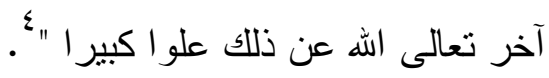

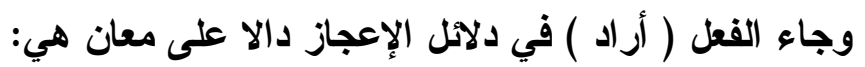

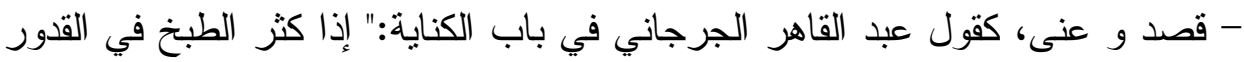
كثر إحراق الحطب تحتها و إذا كثر إحراق الحطب كثر الرماد لا محالة و وكذا السبيل

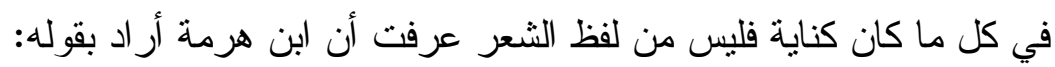

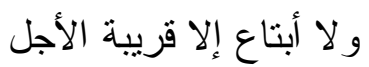

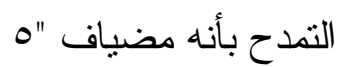

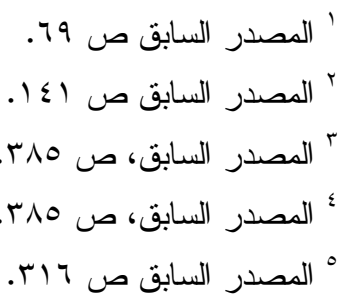




$$
\text { فقول الجرجاني: أراد.... التمدح أي قصدهو عناه. }
$$

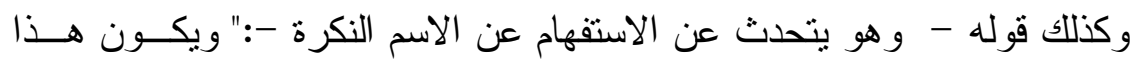

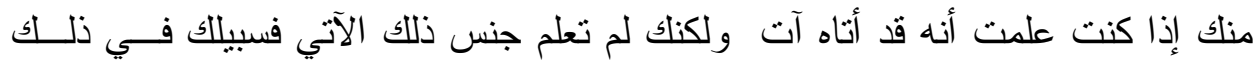

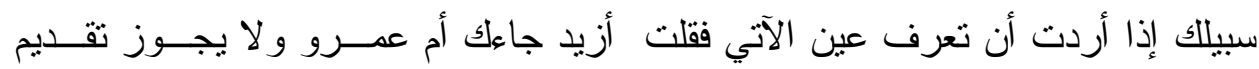

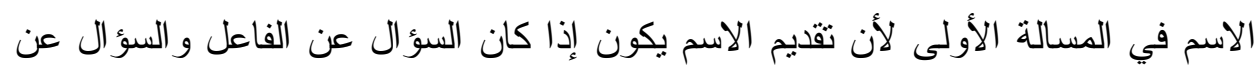

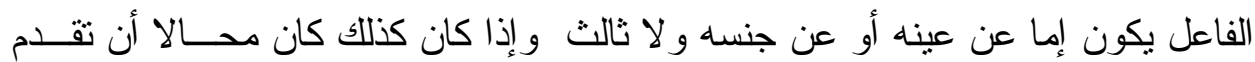

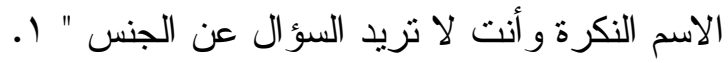

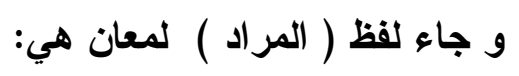

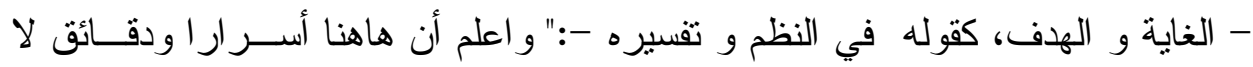

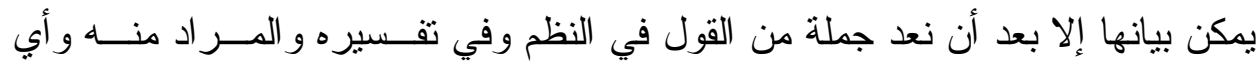
شيء هو وما محصوله ومحصول الفضيلة فيه فينبخي لنا أن نأخذ في ذكره وبيان أمره

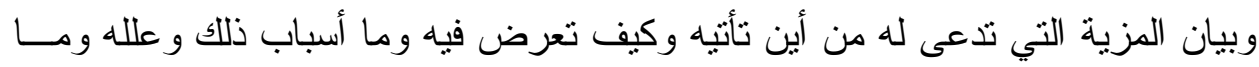

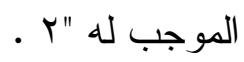

و كذلك قوله:" ونظير هذا قوله تعالى قل آلذكرين حرم أم الأنثيين أما اشتملت

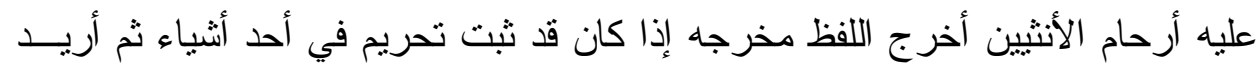

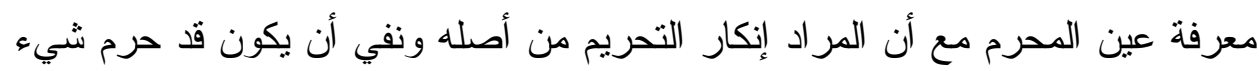

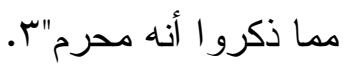

فالمر اد هنا من نص الآية الغاية و الهدف من الخطاب، و يمكن أن يسمى هـــا الهذف فحوى الخطاب.

ومن هذا المعنى قوله معلقا على حذف المفعول به في قول الثاعر :

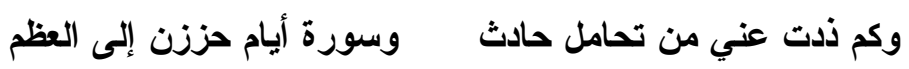

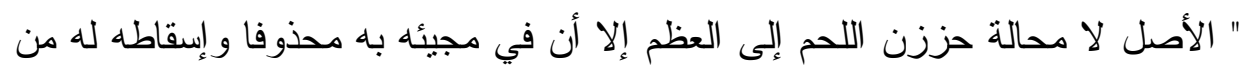

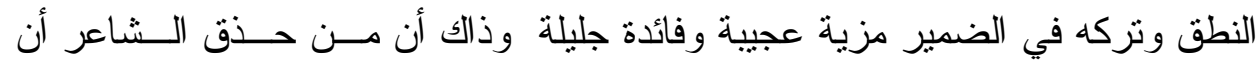

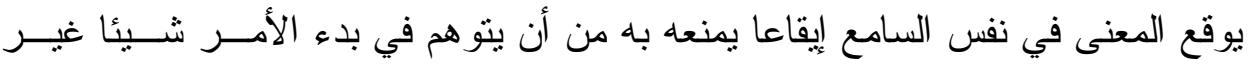

$$
\begin{aligned}
& \text { ' المصدر السابق ص } 199 .
\end{aligned}
$$

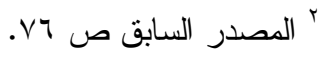

$$
\begin{aligned}
& \text { " المصدر السابق ص ז +. }
\end{aligned}
$$


المر ادثم ينصرف إلى المراد ومعلوم أنه لو أظهر الدفعول فقال وسورة أيسام حـززن

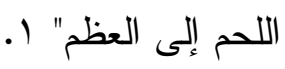

فالمر اد هنا هو الغاية و الهدف الذي قصده الثاعر من حذفه للمفعول به.

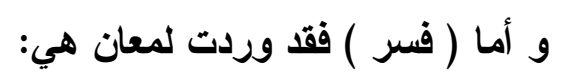

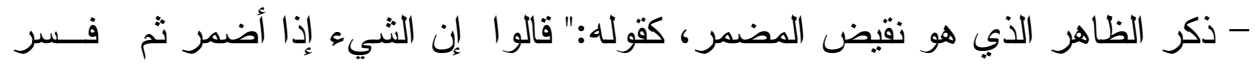

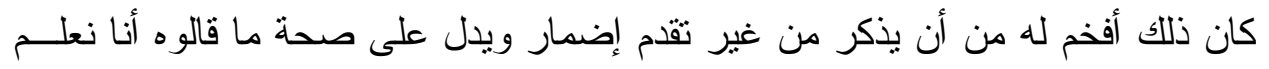

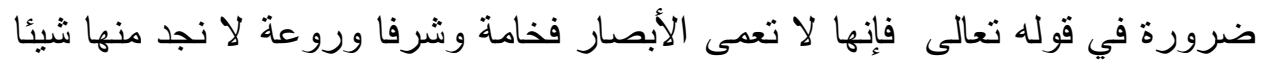

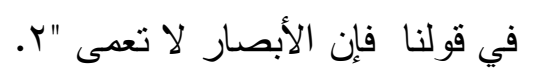

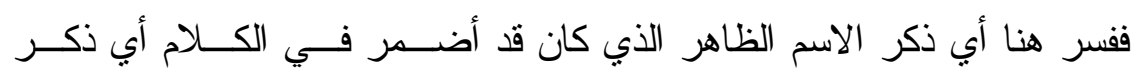

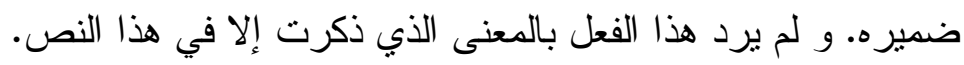

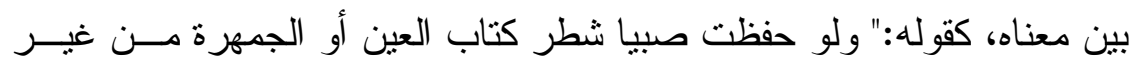

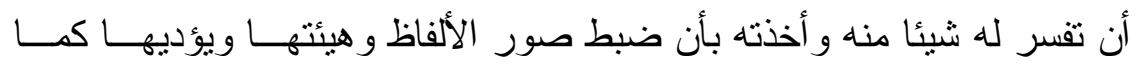

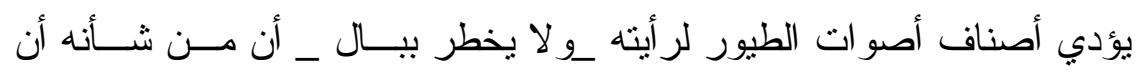

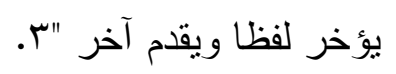

فالجرجاني يبين أن حفظ ما لا معنى له أمر عسير على الذهن، لأن من طبيعة

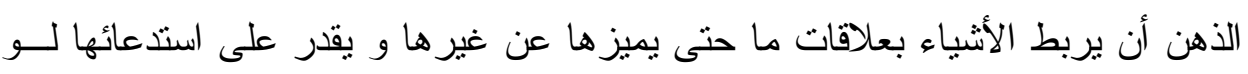

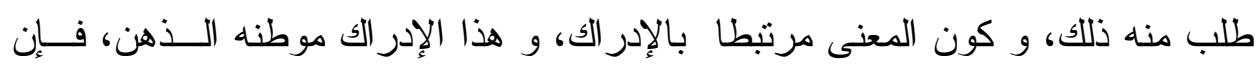
تجلية معنى الألفاظ يعين على حفظها.

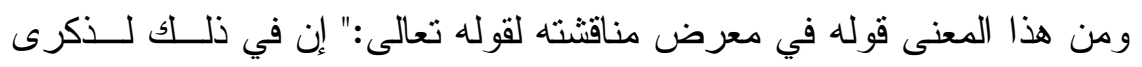

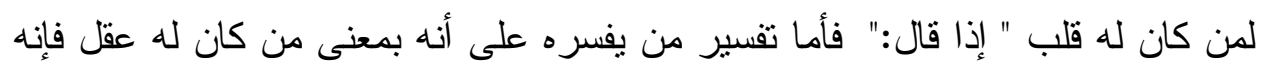

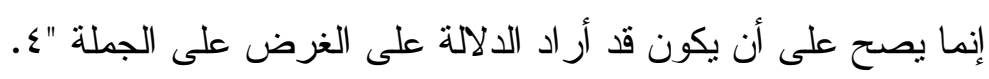
ففسره هنا أي بين معناه، و الدالة الدئ التي يدل عليها هذا المعنى.

$$
\begin{aligned}
& \text { ' المصدر السابق ص و } 1 .
\end{aligned}
$$

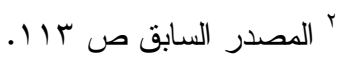

$$
\begin{aligned}
& \text { " المصدر السابق ص } \\
& \text { ؛ المصدر السابق ص ؟ זr. }
\end{aligned}
$$




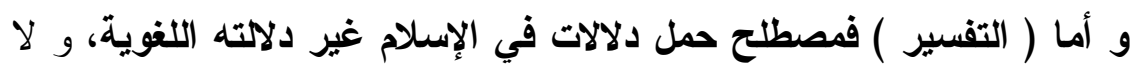

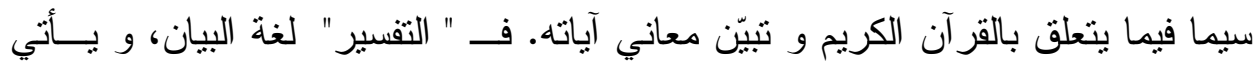

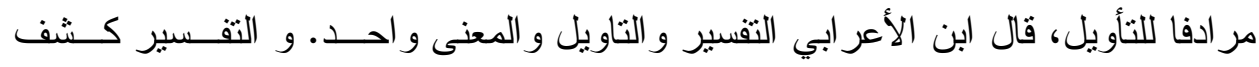

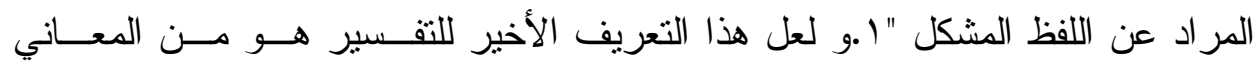

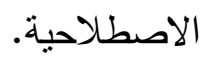

$$
\text { و قد جاء في كتاب دلائل الإعجاز لمعان: }
$$

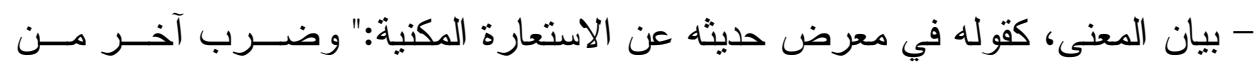
الاستعارة وهو ما كان نحو قوله:

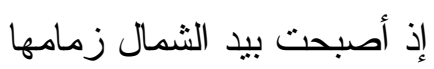

هذا الضرب و إن كان الناس يضمونه إلى الأول حيث يذكرون الاستعارة فلبـسا ســواء

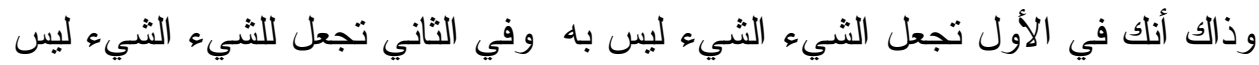

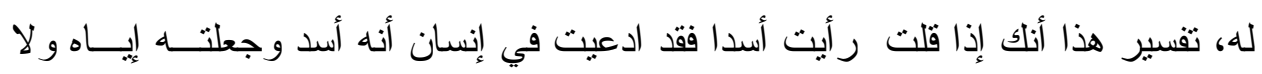

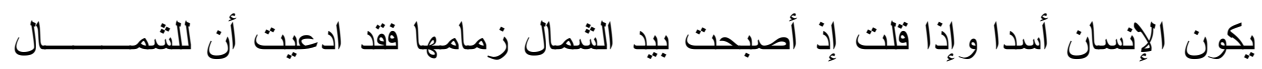

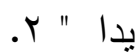

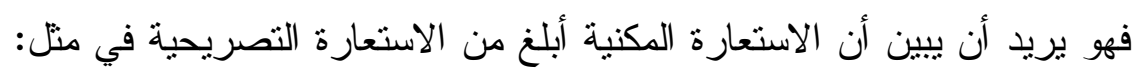

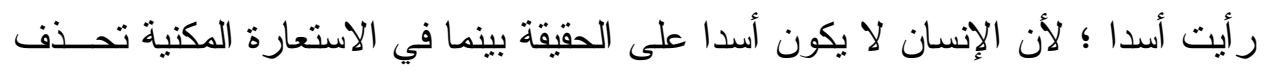

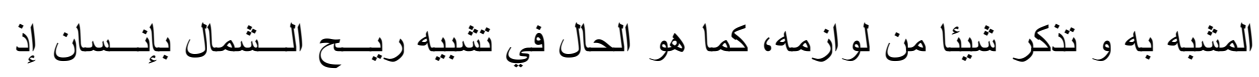
أثبت لها يدا كما هو حال الإنسان.

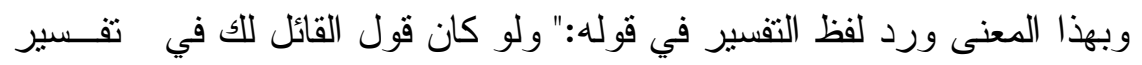

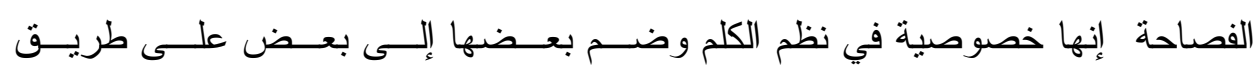

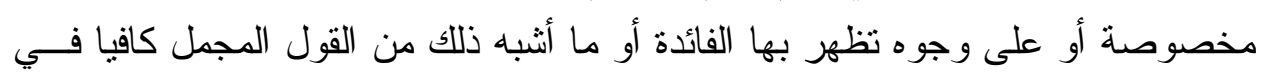

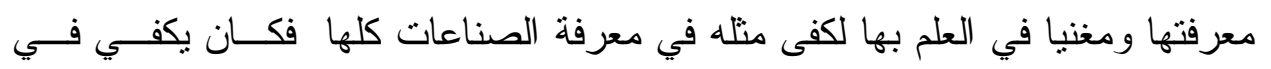

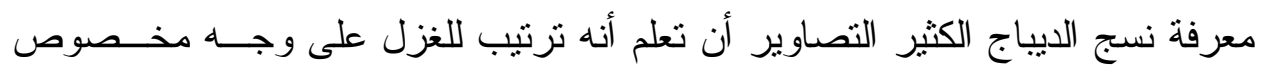

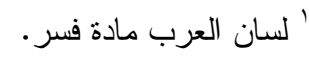

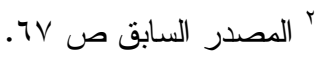


وضم لطاقات الأبريسم بعضها إلى بعض على طرق شتى وذللك ما لا يقوله يقــول بـــــ

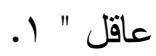
فتفسير الفصاحة هنا أر اد به بيان معناها.

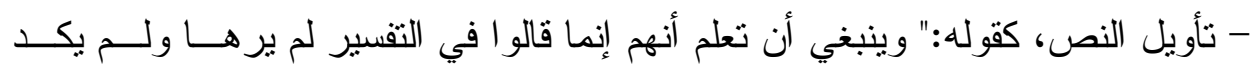

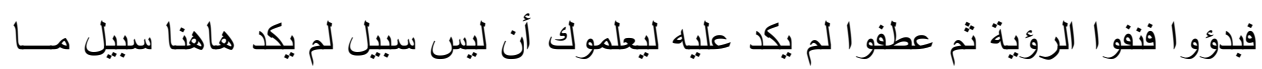

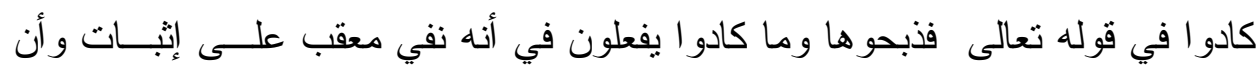

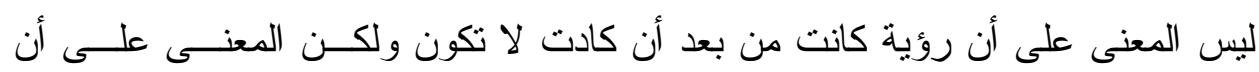

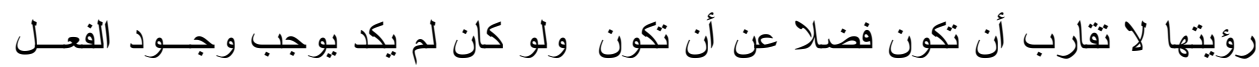

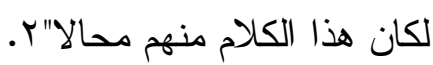

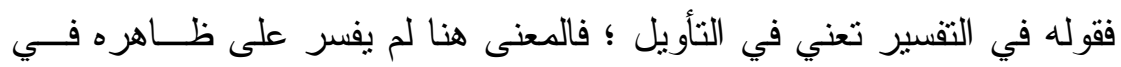

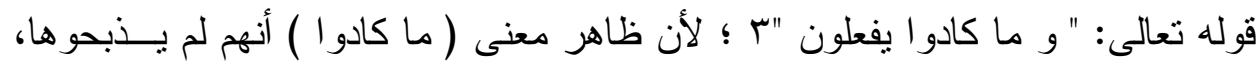

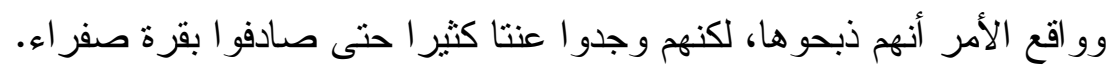

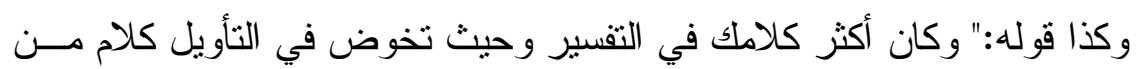

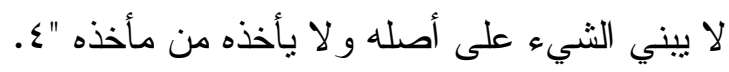

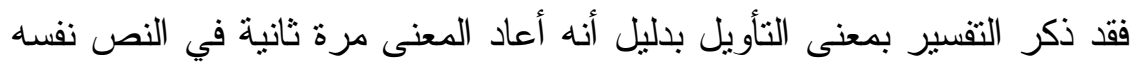

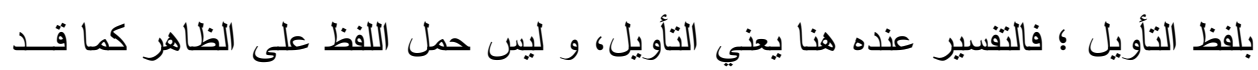
يتو هم.

وكذللك في قوله - تعليقا على الآية الكريمة:" و جعلو ا الملائكة الذين هم عبـاد

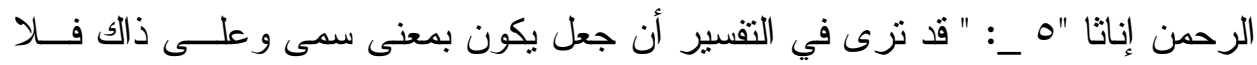

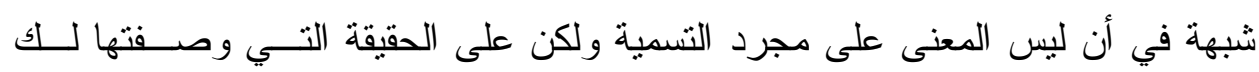

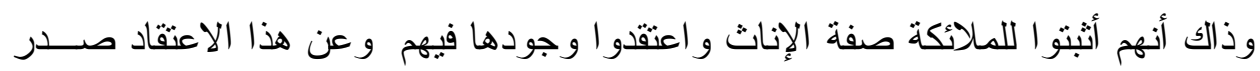

$$
\begin{aligned}
& \text { ' المصدر السابق ص ^^ء. }
\end{aligned}
$$

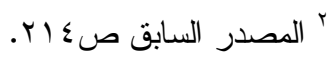

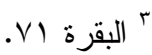

؛ دلائل الإعجاز، عبد القاهر الجرجاني، مصدر سابق ص 99.

$$
\text { مالزخرف } 9 \text { الاند الإن، }
$$




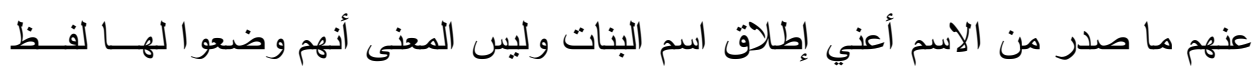

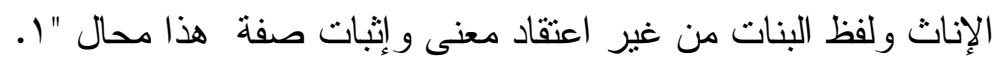

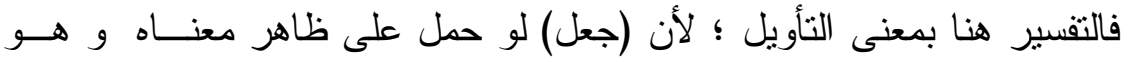

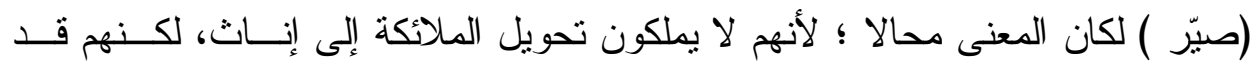
بطلقون عليهم تسمية إناث. - ذكر الظاهر بعد المضمر ، كقوله تعليقا على قول الثاعر:

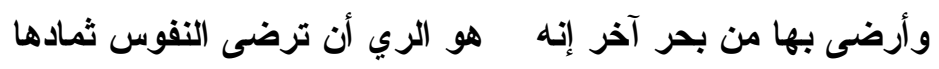

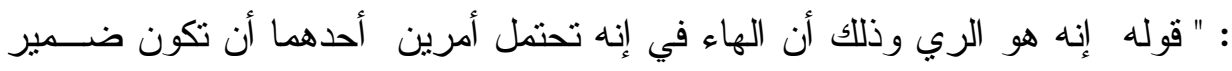

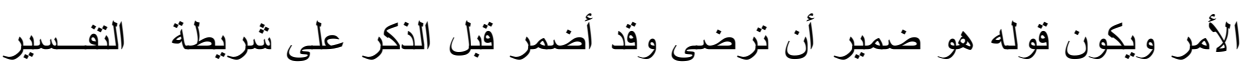

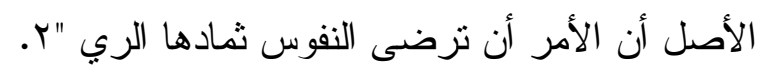

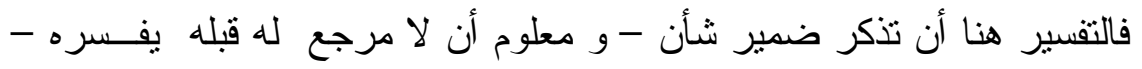
ثم تذكر الجملة التي تبين مدلوله.

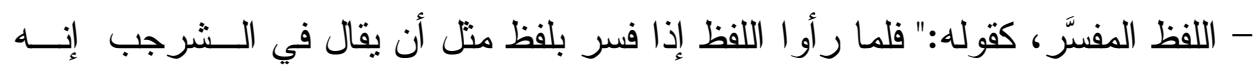

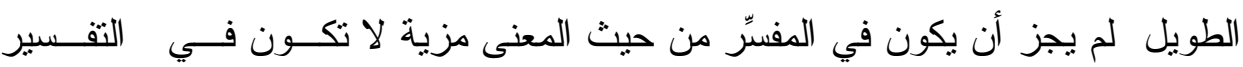

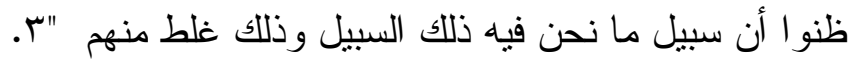

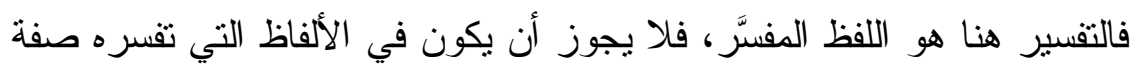

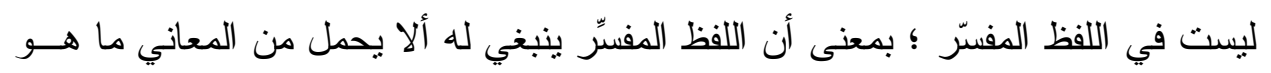
زائد عن معى اللفظ المفسَّر .

وكقوله:" وإذا كان الأمر كذلك ثبت أن الصحيح من أنه لا يجوز أن يكون للفظ

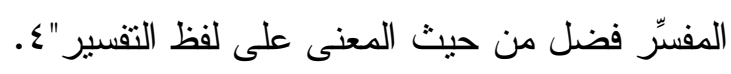

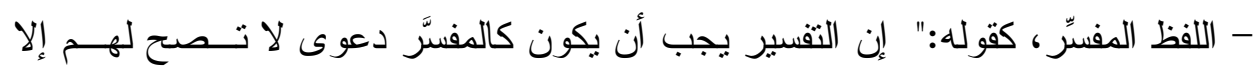

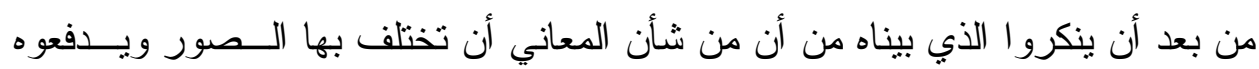

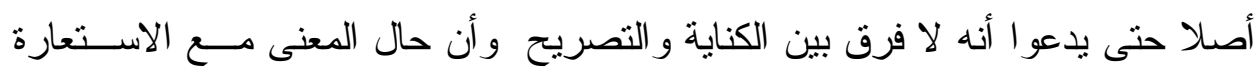

$$
\begin{aligned}
& \text { ' دلائل الإعجاز، عبد القاهر الجرجاني، مصدر سابق ص ابr. }
\end{aligned}
$$

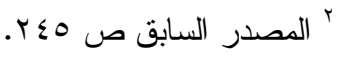

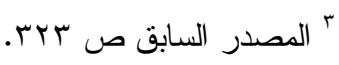

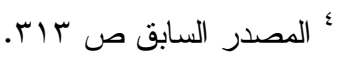


كحاله مع ترك الاستعارة وحتى بطلبو ا ما أطبق عليه العقلاء من أن المجاز يكون أبدا

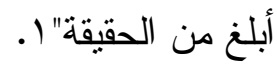

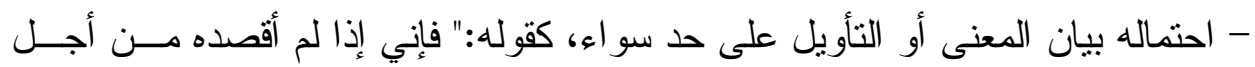

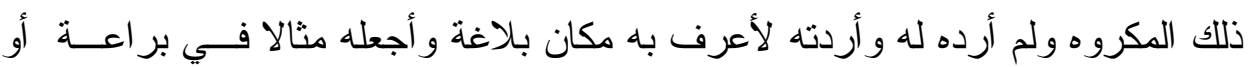

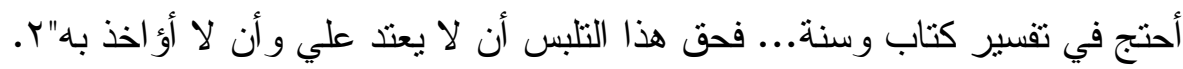

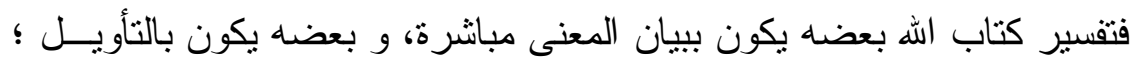

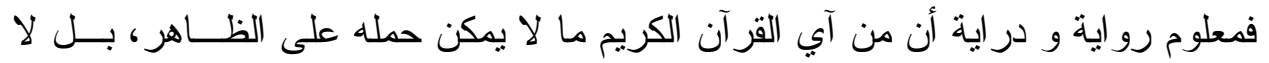
بد فيه من التأويل.

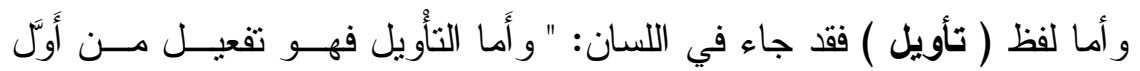

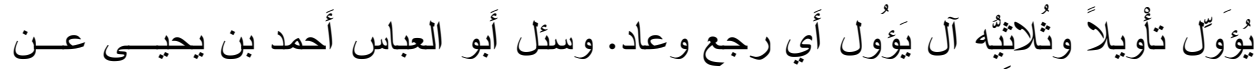

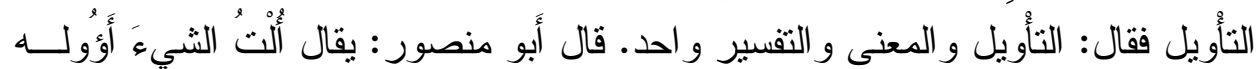

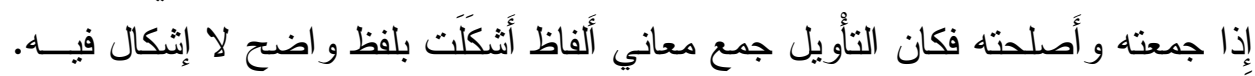

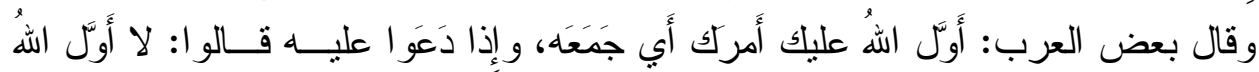

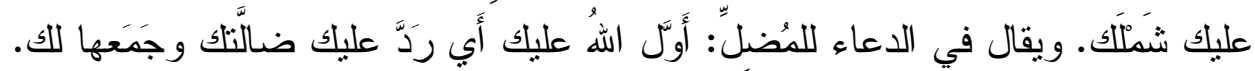

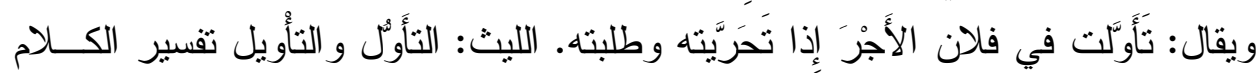

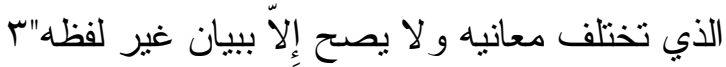

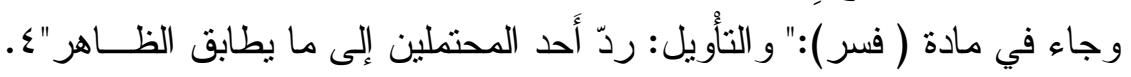
ولعل هذا المعنى هو المعنى الاصطلاحي لهذا اللفظ.

\section{وقد ورد لفظ ( التأويل ) في دلائل الإعجاز لمعان هي:}

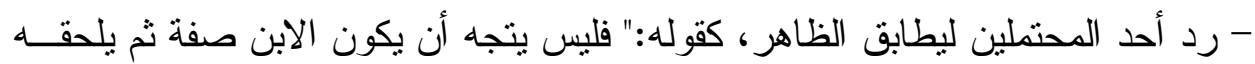

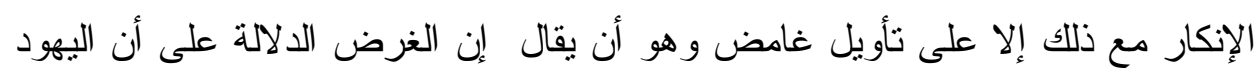

المصدر السابق ص r آب.

r المصدر السابق ص • ع. " لسان العرب، ابن منظور ، مادة أول.

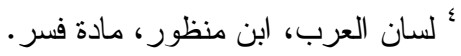


قد كان بلغ من جهلهم ورسوخهم في هذا الثرك أنهـم كــانوا يـــكرون عزيــرا هــذا

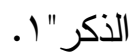

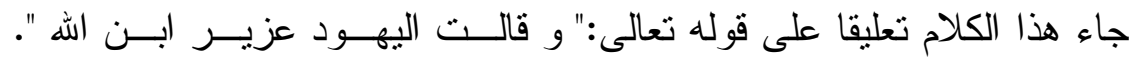

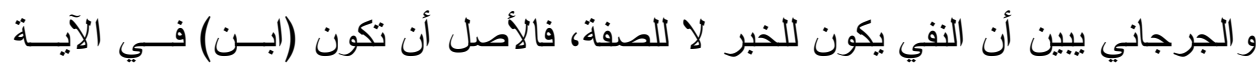

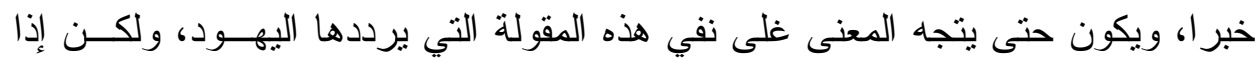

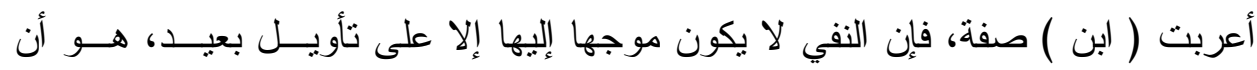
اليهود يذكرون ( عزير) هذا الذكر.

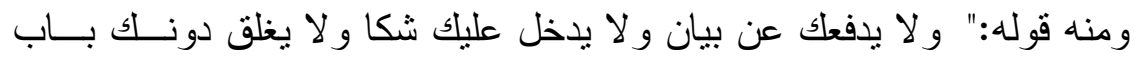

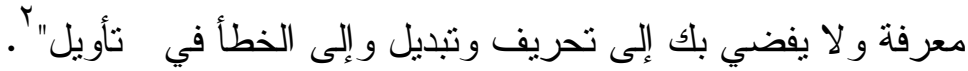

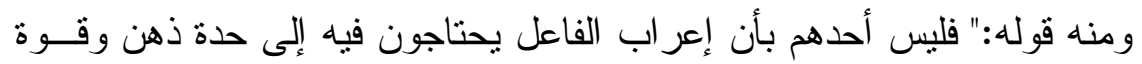
خاطر إنما الذي تقع الحاجة فيه إلى ذلك العلم بما يوجب الفاعلية للثيء إبه إذاعا كان إيجابها

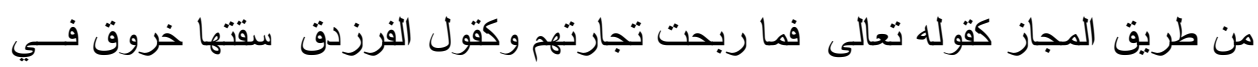

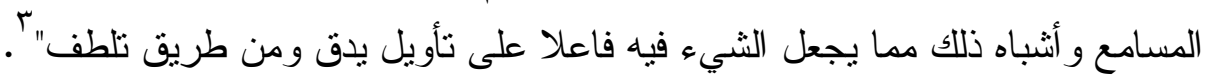
ولم أجد لفظ التأويل بستعمل في دلائل الإعجاز بغير هذا المعنى الذي ذكرت.

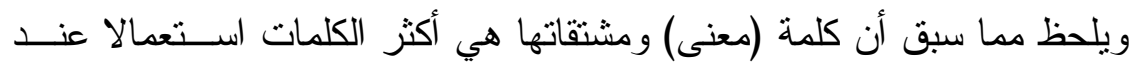

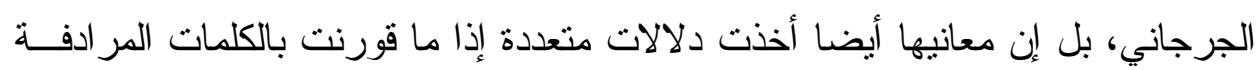

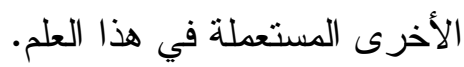

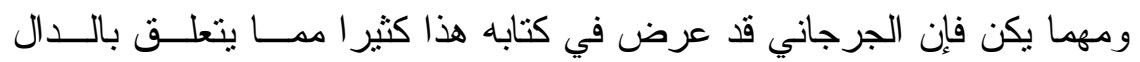
و المدلول مما عرضت إليه تو اليف علم الدلالة حديثا. و الحمد الله رب العالمين

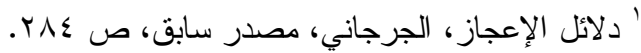

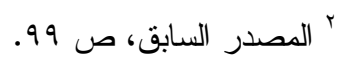

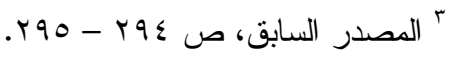




\section{المصادر و المراجع}

ا- التعريفات، علي بن محمد الجرجاني، تحق إبر اهيم الأبياري، دار الريان للتراث، د.ت. دات.

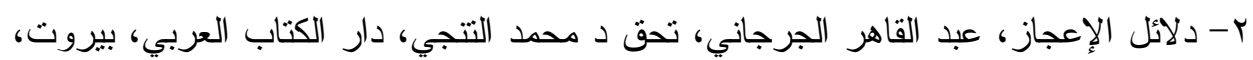
ط 1)،

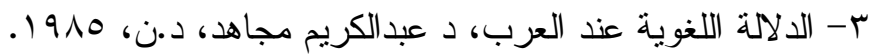

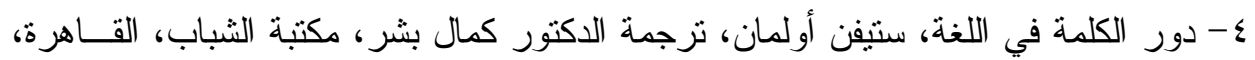
$.19 \vee 0$

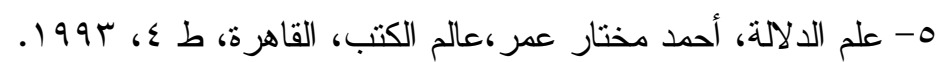

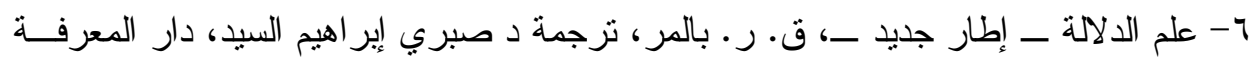
الجامعية، القاهرة، 1990.

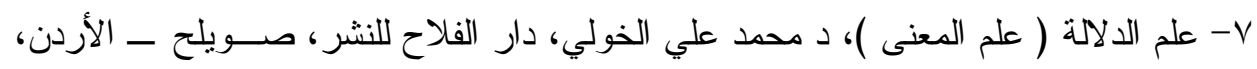
b...

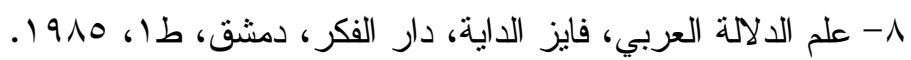

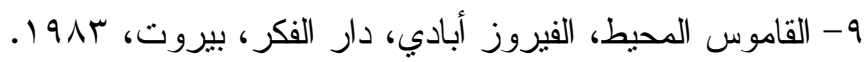

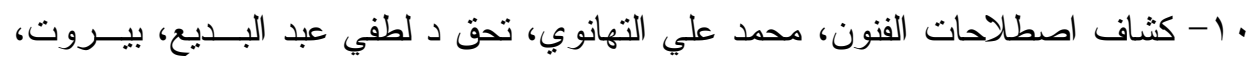
$.19 \times 0$ (1) - لسان العرب، ابن منظور ، بيروت، دار صادر ، د.ت.

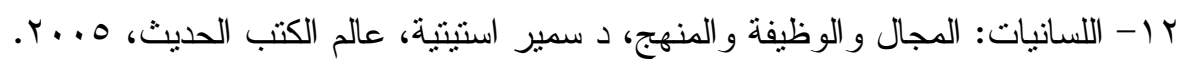

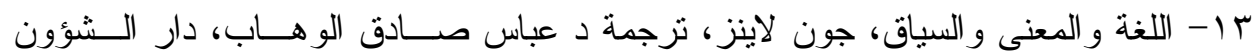

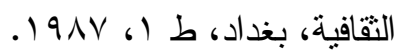

ع ا - المفردات في غريب القر آن، الر اغب الأصفهاني، تحق أحمد خلف الله، القاهرة.د.ت.

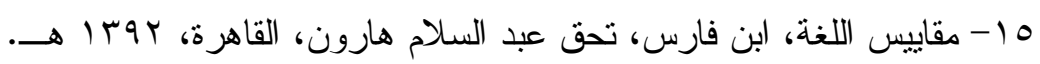


